\title{
BMP Receptor 1A Regulates Development of Hypothalamic Circuits Critical for Feeding Behavior
}

\author{
Chian-Yu Peng, ${ }^{\star \star}$ Abhishek Mukhopadhyay, ${ }^{2 \star}$ Jennifer C. Jarrett, ${ }^{1}$ Kazuaki Yoshikawa, ${ }^{3}$ and John A. Kessler ${ }^{1}$ \\ ${ }^{1}$ Department of Neurology, Northwestern University's Feinberg School of Medicine, Chicago, Illinois 60611, ${ }^{2}$ Department of Genetics, Harvard Medical \\ School, Boston, Massachusetts 02115, and ${ }^{3}$ Laboratory of Regulation of Neuronal Development, Institute for Protein Research, Osaka University, Suita, \\ Osaka 565-0871, Japan
}

Hypothalamic neural circuits are known to regulate energy homeostasis and feeding behavior, but how these circuits are established during development is not well understood. Here we report that embryonic neural progenitors that express the transcription factor OLIG1 contribute neurons to the ventral hypothalamus including the arcuate nucleus (ARH), a center that regulates feeding behavior. Ablation of bone morphogenetic protein receptor 1a (BMPR1A) in the OLIG1 lineage resulted in hypophagia, hypoglycemia, and weight loss after the second postnatal week with death by week 4 . Differentiation and specification of inhibitory hypothalamic neurons contributing to melanocortin and dopaminergic systems were abnormal in the BMPR1A-deficient ARH. Although the hypophagia promoted expression of the orexigenic neuropeptide agouti related protein (AgRP) in the BMPR1A-deficient ARH, there was a profound decrease of AgRP ${ }^{+}$axonal terminals in the mutant ARH targets including dorsomedial and paraventricular hypothalamic nuclei. Projection of $\mathrm{AgRP}^{+}$neurons to these nuclei is known to be regulated by leptin. Leptin injection in neonatal mice increased bone morphogenic protein (BMP) signaling in the ventral hypothalamus, and blocking BMP signaling prevented leptin-induced neurite outgrowth in ARH explant cultures. These findings suggest that BMPR1A signaling is critical for postnatal establishment of leptin-responsive orexigenic fibers from ARH to multiple hypothalamic nuclei. More generally these observations indicate that BMPR1A signaling regulates postnatal establishment of OLIG1 lineage-derived ARH neuronal circuits that are critical for leptin-mediated feeding behavior.

\section{Introduction}

The hypothalamus regulates many aspects of feeding behavior and energy homeostasis in response to signals from the periphery. For example, leptin (Zhang et al., 1994), an adipocytederived hormone, inhibits food intake and promotes catabolic responses through neural circuits involving multiple nuclei of the ventral hypothalamus. Central to the circuit are two distinct neuronal populations located in the arcuate nucleus of hypothalamus (ARH) that express either proopiomelanocortin (POMC) or agouti-related protein $(\mathrm{AgRP}) /$ neuropeptide $\mathrm{Y}(\mathrm{NPY}) . \mathrm{AgRP}^{+} /$ $\mathrm{NPY}^{+}$neurons are orexigenic and inhibited by increased circulating levels of leptin whereas $\mathrm{POMC}^{+}$neurons are anorexigenic and stimulated by leptin. These ARH neurons project directly to nuclei including the dorsomedial hypothalamus, paraventricular nucleus of the hypothalamus (PVH), and lateral hypothalamus

Received May 23, 2012; revised 0ct. 5, 2012; accepted 0ct. 8, 2012.

Author contributions: C.-Y.P., A.M., and J.A.K. designed research; C.-Y.P., A.M., and J.C.J. performed research; K.Y. contributed unpublished reagents/analytic tools; C.Y.P., A.M., and J.C.J. analyzed data; C.-Y.P., A.M., and J.A.K. wrote the paper.

This project was supported by National Institutes of Health Grants NS 20013 and NS 20778. We thank Yuji Mishina for providing us the Bmpr1a, David Rowitch for the OLIG1-cre, and Karen Lyons and Henry Kronenberg for the Bmpr $1 b$ mouse lines. We thank Lixin Kan and Jayshree Samanta for technical assistance and manuscript discussion.

${ }^{*}$ C.-Y.P. and A.M. contributed equally to this work.

The authors declare no competing financial interests.

Correspondence should be addressed to Chian-Yu Peng, Department of Neurology, Northwestern University's Feinberg School of Medicine, Chicago, IL 60611. E-mail: c-peng@northwestern.edu.

DOI:10.1523/JNEUROSCI.2484-12.2012

Copyright $\odot 2012$ the authors $\quad 0270-6474 / 12 / 3217211-14 \$ 15.00 / 0$ area, which all play important roles in leptin-regulated feeding behavior (Cone, 2005; Gautron and Elmquist, 2011).

Despite advances in the understanding of hypothalamic regulation of feeding behavior, molecular mechanisms involved in development of ARH neural circuits remain limited. During embryonic development, $\mathrm{POMC}^{+}$and $\mathrm{NPY}^{+} \mathrm{ARH}$ neurons are generated from Nkx2.1 ${ }^{+}$progenitors (Yee et al., 2009), and several other transcription factors have been implicated in hypothalamic neuroendocrine development and function (Caqueret et al., 2005; McNay et al., 2006; Shimogori et al., 2010). Hypothalamic neuronal differentiation is regulated by sequential actions of floor plate-secreted signaling ligands sonic hedgehog $(\mathrm{SHH})$ and bone morphogenetic protein 7 (BMP7) (Ohyama et al., 2005; 2008). BMP signaling is mediated by a heterodimeric complex of type I (BMPR1A, BMPR1B, and ALK2) and type II (BMPR2) receptors, which canonically lead to the phosphorylation and nuclear translocation of the SMAD family effector proteins (Shi and Massagué, 2003). Disruption of signaling through BMPR1A in cells that express the transcription factor OLIG1 causes mutant mice to fail to gain weight normally and die by 4 weeks of age (Samanta et al., 2007). OLIG1 is expressed throughout the ventral neural tube including developing telencephalon and diencephalon, where OLIG1-expressing progenitors differentiate into interneurons and oligodendrocytes (Takebayashi et al., 2000; Lu et al., 2002; Samanta et al., 2007; Mukhopadhyay et al., 2009). Although OLIG1 lineage neurons were not known to populate hypothalamic nuclei, the feeding abnormalities in mice with OLIG1 
lineage deletion of BMPR1A suggested to us disruption of hypothalamic function.

Here we show that the OLIG1 lineage gives rise to three neuronal subtypes in the ARH. Ablation of Bmprla in the OLIG1 lineage resulted in hypophagia-induced AgRP upregulation and POMC downregulation in ARH at postnatal day 21 (P21). Despite increased expression of AgRP in cell bodies, $\mathrm{AgRP}^{+}$axon terminals were greatly reduced at the target nuclei. Since projection of ARH neurons is regulated by leptin, this suggested that BMP signaling may be necessary for leptin-mediated axon outgrowth. In support of this hypothesis, we found that leptin injection in neonatal mice increased BMP signaling in the ventral hypothalamus, and blocking BMP signaling with the antagonist noggin prevented leptin-induced neurite outgrowth in ARH explant cultures. These findings suggest that BMPR1A signaling is critical for postnatal establishment of leptin-responsive orexigenic fibers from ARH to multiple hypothalamic nuclei.

\section{Materials and Methods}

Generation and maintenance of mouse lines. OLIG1-cre $\left(O L I G 1^{\text {cre/cre }}\right)$ mice were maintained in a C57BL/6 background while Bmprla floxed (Bmprla $\left.a^{f x / f x}\right)$, $\mathrm{Bmprla}^{+/-}$, and Bmprlb ${ }^{+/-}$were maintained in a 129Sv:C57BL/6 mixed background. The generation of the OLIG1-cre, Bmprla $a^{f x / f x}, B m p r 1 b^{+/-}$, and $B_{\text {mprlb }}^{+/-}$has already been reported (Mukhopadhyay et al., 2009). The OLIGI ${ }^{\text {cre/cre }}$ mice were bred to Bmprla ${ }^{+/-}$to get $O L I G 1^{\text {cre/+ }} ; \mathrm{Bmprla}^{+/-}$, which were then bred to Bmprlb $b^{+/-}$to generate the OLIG1 ${ }^{\text {cre/cre; }}$; Bmprla $^{+/-} ; B_{\text {Bmprla }}^{+/-}$. The Bmprla ${ }^{f x / f x}$ animals were bred to Bmprlb $b^{+/-}$ to generate the Bmprla $a^{f x / f x}$; Bmprlb ${ }^{+/-}$, which were then bred to the ROSA lacz/acz (Jackson Laboratories) to generate Bmprla $a^{f x / f x}$; Bmprlb ${ }^{+/-}$; ROSA $^{\text {lacZlacz }}$. In the final mating OLIG1 $1^{\text {cre/cre }} ;$ Bmprla $^{+/-} ;$Bmprlb $^{+/-}$animals were bred to Bmprla $a^{\text {fx/fx }}$; Bmprlb ${ }^{+/}$; ROSA lacZ/acz to get OLIGI ${ }^{\text {cre/+}}$; Bmprla $^{f \times /+}$; Bmprlb ${ }^{+/-}$; ROSA lacz/+ (control), OLIG1 ${ }^{\text {crel+ }} ;$ Bmprla $^{f x /-}$;

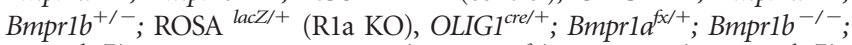
$\mathrm{ROSA}^{\text {lacZ/+ }}(\mathrm{R} 1 \mathrm{~b} \mathrm{KO})$, and OLIGI ${ }^{c r e l+} ;$ Bmprla $^{\mathrm{fx} /-} ; \mathrm{Bmprlb}^{-/-}$; ROSA ${ }^{\text {lacZ/+ }}$ $(\mathrm{R} 1 \mathrm{a} / \mathrm{b} \mathrm{KO})$ animals. Male mice of each genotype were selected for all postnatal body weight and cellular analyses. The excision of the Bmprla floxed allele by the OLIG1-cre expression has already been reported (Samanta et al., 2007). All animal experiments were conducted in conformation to the regulatory standards laid down by the Northwestern University Animal Care and Use Committee.

Immunohistochemistry, in situ hybridization, and EdU labeling. Mice were transcardially perfused with cold HBSS medium (Invitrogen) and the brains were fixed in $4 \%$ paraformaldehyde (PFA) for $2 \mathrm{~h}$. The fixed brains were cryoprotected in $30 \%$ sucrose solution overnight and frozen in Tissue-Tek OCT before being cryosectioned for immunohistochemistry. The tissue sections were incubated with primary antibody overnight at $4^{\circ} \mathrm{C}$ in PBS containing $1 \%$ bovine serum albumin (BSA), $0.25 \%$ Triton X-100, and $2 \%$ goat serum. After a second set of washes the cell and the tissue sections were incubated with fluorophore-conjugated Alexa Fluor goat secondary antibodies (1:500) (Invitrogen) in a solution containing $1 \%$ BSA, $0.25 \%$ Triton X-100, and DAPI nuclear stain (Invitrogen) for $1 \mathrm{~h}$. After a second set of washes, the slides were mounted in ProLong Gold antifade reagent (Invitrogen). The primary antibodies used were mouse anti NKX2.1 (1:200; Thermo Fisher), rabbit anti-PAX6 (1:2000; Millipore), rabbit anti-OLIG2 (1: 500; Millipore), goat antiOLIG2 (1:500; R\&D), rabbit anti-ASCL1 (1:1000; BD Pharmingen), guinea pig anti-DLX2 (1:3000), rabbit anti-cleaved caspase 3 (1:1000; Cell Signaling Technology), rabbit anti-tyrosine hydroxylase (TH; 1:1000; Pel Freez), mouse anti-TH (1:500; Sigma), rabbit anti-POMC (1:1000; Phoenix Pharmaceuticals), rabbit anti-NPY (1:1000; Phoenix Pharmaceuticals), rabbit anti-AgRP (1:2000; Phoenix Pharmaceuticals), guinea pig anti-AgRP (1:2000; Abnova), rabbit anti-MC4R (1:250; Alomone Labs), sheep anti- $\alpha$-MSH (1:10,000, Millipore), rabbit anti- $\beta$ galactosidase (1:2000, Covance), chick anti- $\beta$-galactosidase (1:500, Fitzgerald Scientific), rabbit anti-BMPR1A (Abgent AP2004a, 1:200), rabbit anti-phospho-SMAD1/5/8 (1:300; Cell Signaling Technology), rabbit anti-phospho-STAT3 (1:1000, Cell Signaling Technology). For mRNA expression analysis of POMC and AgRP, plasmids containing full-length POMC and AgRP cDNA were purchased (Open Biosystems) and used to generated digoxigenin-labeled antisense RNA probes to use for in situ hybridization as previously described (Mukhopadhyay et al., 2009). For EdU labeling pregnant dams were give one injection (10 ml/ $\mathrm{kg}$ ) of EdU (Invitrogen) solution $(2.5 \mathrm{mg} / \mathrm{ml})$ intraperitoneally. To assess proliferation and cell cycle exit, the embryos were collected 1 or $24 \mathrm{~h}$ post-EdU injection, respectively. For phospho-SMAD1/5/8 and phospho-STAT3 staining, recombinant leptin $(5 \mathrm{mg} / \mathrm{kg}$; R\&D) or vehicle (PBS) is injected intraperitoneally into wild-type mice at P7 and killed at $45 \mathrm{~min}$ or $3 \mathrm{~h}$ postinjection. All tissue was processed as described above for immunohistochemistry. Immunohistochemistry was followed by staining for EdU using Clik-IT EdU Imaging Kit (Invitrogen) following manufacturer's instructions.

$X$-gal staining. Tissue sections were washed in rinse buffer (PBS with $0.01 \%$ deoxycholate, $5 \mathrm{~mm}$ EGTA, $0.02 \% \mathrm{NP} 40$, and $2 \mathrm{~mm} \mathrm{MgCl}_{2}$ ) for 10 min twice. After the washes the slides were incubated in staining buffer (PBS with $5 \mathrm{~mm} \mathrm{~K}_{3} \mathrm{Fe}(\mathrm{CN})_{6}, 5 \mathrm{~mm} \mathrm{~K}_{4} \mathrm{Fe}(\mathrm{CN})_{6}, 0.01 \%$ deoxycholate, 5 mM EGTA, $0.02 \% \mathrm{NP} 40,2 \mathrm{~mm} \mathrm{MgCl}$, and $1 \mathrm{mg} / \mathrm{ml} \mathrm{X-gal)} \mathrm{at} 37^{\circ} \mathrm{C}$ until sufficient staining was detected. The slides were washed with PBS and incubated in primary antibody overnight at $4^{\circ} \mathrm{C}$ in PBS containing $1 \%$ BSA, $0.25 \%$ Triton $\mathrm{X}-100$, and $2 \%$ goat serum. The following day the slides were washed in PBS and incubated in biotinylated secondary antibodies, which were then peroxidase conjugated as per manufacturer's instructions in VECTASTAIN Elite ABC Reagent Kit (Vector Laboratories). A red stain was developed using the AEC substrate kit for peroxidase (Vector Laboratories).

Blood glucose and serum hormone measurements. Blood glucose was measured from a drop of blood from the tail vein using Ascensia Contour Blood Glucose Monitoring System (Bayer) as per manufacturer's instructions. For serum hormone measurements, blood samples were left at room temperature for $45 \mathrm{~min}$ to allow coagulation and spun at 14,000 $\mathrm{rpm}$ for $10 \mathrm{~min}$. The supernatant was collected, aliquoted, and stored at $-80^{\circ} \mathrm{C}$ until further use. Ghrelin, leptin, and insulin concentrations were determined by multiplex ELISA using the Milliplex MAP Mouse Gut Hormone Panel (Millipore) following manufacturer's instructions.

ARH explant culture. Slice and explant culture was performed based on a modified protocol from the Simerly and Hevner labs (Bouret et al., 2004; Daza et al., 2007). Briefly, brains of P7 C57BL6 pups were dissected, embedded in $4 \%$ low melting point agarose, and sectioned in ice-cold KREB buffer to $200-\mu \mathrm{m}$-thick slices using a vibratome (Leica VT1000S). The ARH was isolated under a dissecting microscope and placed inside a $30 \mu \mathrm{l}$ droplet of $4 \mathrm{mg} / \mathrm{ml}$ rat tail collagen solution (Millipore) on glass coverslips. Collagen matrix was allowed to set for $30 \mathrm{~min}$ before serum ad libitum growth media with either vehicle, leptin (100 ng/ml; R\&D 498OB), or leptin plus Noggin $(250 \mathrm{ng} / \mathrm{ml}$; R\&D 719-NG) was added to the wells ( $n=6-8$ per condition). Slices were cultured at $37^{\circ} \mathrm{C}$ with $5 \% \mathrm{CO}_{2}$ for $3 \mathrm{~d}$ with fresh media exchanged daily, and then fixed with $4 \%$ PFA before immunostaining with $\beta$-III tubulin (1:1000; Sigma) and analyzed on a confocal microscope (Leica SP5). For neurite outgrowth quantification, a $z$-series stack through the entire slice was merged, binarized, and skeletonized using National Institutes of Health (NIH) ImageJ. Per pixelintegrated density of the image field, excluding the explant itself was calculated and compared between experimental conditions.

Cell counts and statistical analysis. Coronal adult mouse brain sections $(10 \mu \mathrm{m})$ close to bregma $-0.1 \mathrm{~mm}$ and bregma $+1.7 \mathrm{~mm}$, based on landmarks defined by the Paxinos Atlas of the Mouse Brain, were used for analysis of the rostral hypothalamus (RH) and the tuberal hypothalamus $(\mathrm{TuH})$, respectively. Images of the different hypothalamic nuclei were obtained from four brain sections separated by $40 \mu \mathrm{m}$ using a Zeiss Axiovert epifluorescence microscope and counted manually using NIH ImageJ software. The ImageJ software was also used to measure the area of the hypothalamic nuclei from which the cells were counted. To study colocalization, images were acquired using a Zeiss UV LSM510 confocal scanning microscope. All counts and image acquisitions were performed blinded. In experiments with only two conditions Student's $t$ test assuming unequal variance was used while for multicondition experiments one-way ANOVA followed by Tukey's post hoc text was used to determine statistical significance. All data are presented as mean \pm SEM. 

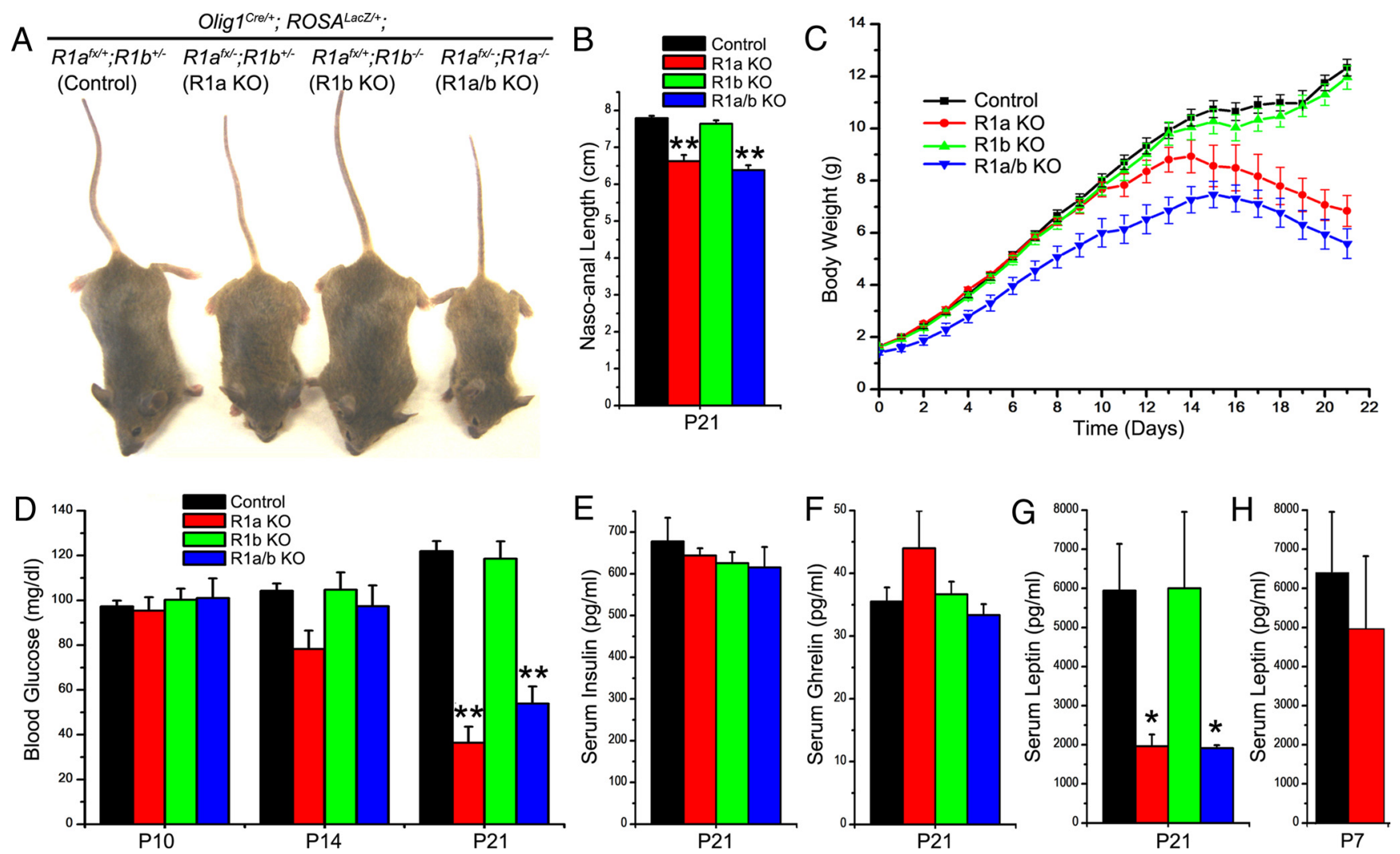

Figure 1. Bmpr1a mutant mice are hypophagic and lean. $A$, A litter representing the four genotypes, control, R1a K0, R1b K0, and R1a/b K0 mice at P21. $B$, Average body lengths of the control and mutant male mice. Note the significantly smaller size of the R1a KO and R1a/b KO mice $(A, B)$. $C$, Body weights of the control and mutant male mice from the day of birth to P21. Note the weight loss after P14 in R1a K0 and R1a/b K0 mice. D, Blood glucose levels at P21. Note that R1a and R1a/b K0 mice are mildly hypoglycemic at P14 and severely hypoglycemic by P21. $\boldsymbol{E}-\boldsymbol{H}, \mathbf{S e r u m}$ concentrations of insulin $(\boldsymbol{E})$, ghrelin $(\boldsymbol{F})$, and leptin $(\boldsymbol{G}, \boldsymbol{H})$ in the control and mutant mice at revealed significant reduction of circulating leptin levels at P21 $(\boldsymbol{G})$ but normal leptin levels at P7 $(\boldsymbol{H})$. All data are presented as mean \pm SEM. ${ }^{*} p<0.05,{ }^{* *} p<0.01$ ANOVA.

\section{Results}

Mice lacking BMPR1A signaling in OLIG1 lineage cells are hypophagic and lean

We previously reported that mice with OLIG1 lineage-specific deletion of Bmprla weigh less than littermate controls at P20 and do not survive past P25 (Samanta et al., 2007). To further investigate the role of BMP receptors (BMPRs) in development of OLIG1 lineage cells, we generated mice carrying a lac $Z$ reporter and mutant for Bmprla (R1a KO) (OLIG1 ${ }^{\text {crel }} ; B m p r l a^{f x /}$; Bmprlb $^{+/}$; ROSA $\mathrm{A}^{\text {lacZ/+ }}$ ), Bmprlb (R1b KO), or both (R1a/b KO)

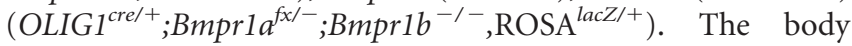
weights of newborn R1a KO mice were comparable to control

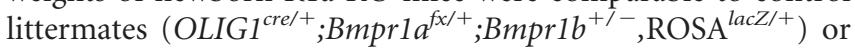
R1b KO mice until P10 when their growth rates slowed and ultimately turned negative after P16 (Fig. 1C). R1a/b KO mice had only slightly slower growth rates until P10 when they slowed further and paralleled R1a KO mice thereafter (Fig. 1C). At P21, $\mathrm{R} 1 \mathrm{a} \mathrm{KO}$ and $\mathrm{R} 1 \mathrm{a} / \mathrm{b} \mathrm{KO}$ mice were distinguishable from control littermates by their smaller sizes (Fig. 1A), hypoactivity, and poorly groomed coats. At P21 the body lengths (naso-anal) of $\mathrm{R} 1 \mathrm{a} \mathrm{KO}$ and $\mathrm{R} 1 \mathrm{a} / \mathrm{b} \mathrm{KO}$ mice were reduced $\sim 15$ and $18 \%$, respectively, compared with control (Fig. $1 B$; Control: $7.7 \pm 0.1 \mathrm{~cm}$; R1a KO: $6.6 \pm 0.2 \mathrm{~cm}$; R1b KO: $7.6 \pm 0.1 \mathrm{~cm}$; R1a/b KO: $6.4 \pm 0.1$ $\mathrm{cm} ; p<0.01$ ), and R1a KO and R1a/b KO mice weighed $\sim 45$ and $55 \%$ less than controls (Control: $12.3 \pm 0.3$ g; R1a KO: $6.8 \pm$ 0.6 g; R1b KO: $12.0 \pm 0.4$ g; R1a/b KO: $5.6 \pm 0.6$ g; $p<0.01$ ). Since growth of R1b KO mice was not affected, the weight loss was attributable to loss of Bmprla in OLIG1 lineage cells.
The severe anorexia in R1a KO and R1a/b KO mice was accompanied by $\sim 70$ and 56 reductions, respectively, in blood glucose levels at P21 (Fig. 1D; Control: $122.0 \pm 4.5 \mathrm{mg} / \mathrm{dl}$; R1a KO: $36.4 \pm 7.1 \mathrm{mg} / \mathrm{dl}$; R1b KO: $118.6 \pm 7.8 \mathrm{mg} / \mathrm{dl}$; R1a/b KO: $53.9 \pm$ $7.6 \mathrm{mg} / \mathrm{dl} ; p<0.01)$. Mutations in TGF- $\beta$ signaling, which is closely related to BMP signaling, cause hypoglycemia due to hyperinsulinemia (Bouret and Simerly, 2007). However, serum insulin and orexigenic hormone ghrelin concentrations of the mutant mice were comparable to controls (Fig. $1 E, F$ ). In contrast, plasma levels of the anorexigenic hormone leptin were reduced $\sim 70 \%$ both in R1a KO and R1a/b KO mice (Control: $5940.2 \pm 1194.2$ pg/ml; R1a KO: $1960.9 \pm 302.4$ pg/ml; R1b KO: $6003.1 \pm 1954.1 \mathrm{pg} / \mathrm{ml} ; \mathrm{R} 1 \mathrm{a} / \mathrm{b} \mathrm{KO}: 1910.8 \pm 81.3 \mathrm{pg} / \mathrm{ml} ; p<$ 0.05 ) at P21 (Fig. 1G). To exclude the possibility that R1A deletion in the OLIG1 lineage leads to global reduction of leptin production, we examined plasma leptin levels before the onset of hypophagia at P7, and found no significant differences between R1a KO and control (Fig. 1H). These observations suggest that leptin is produced normally in R1a KO mice, but is subsequently downregulated at P21 as the result of starvation.

\section{Bmpr1a mutant mice exhibit hypophagia-induced neuropeptide alterations in the ARH}

Targets of circulating leptin include ARH neurons that form the central melanocortin pathway (Tartaglia et al., 1995; Cheung et al., 1997; Cowley et al., 2001). Subpopulations of ARH neurons upregulate POMC or downregulate NPY/AgRP expression in response to leptin signaling to modulate energy balance (Stephens 


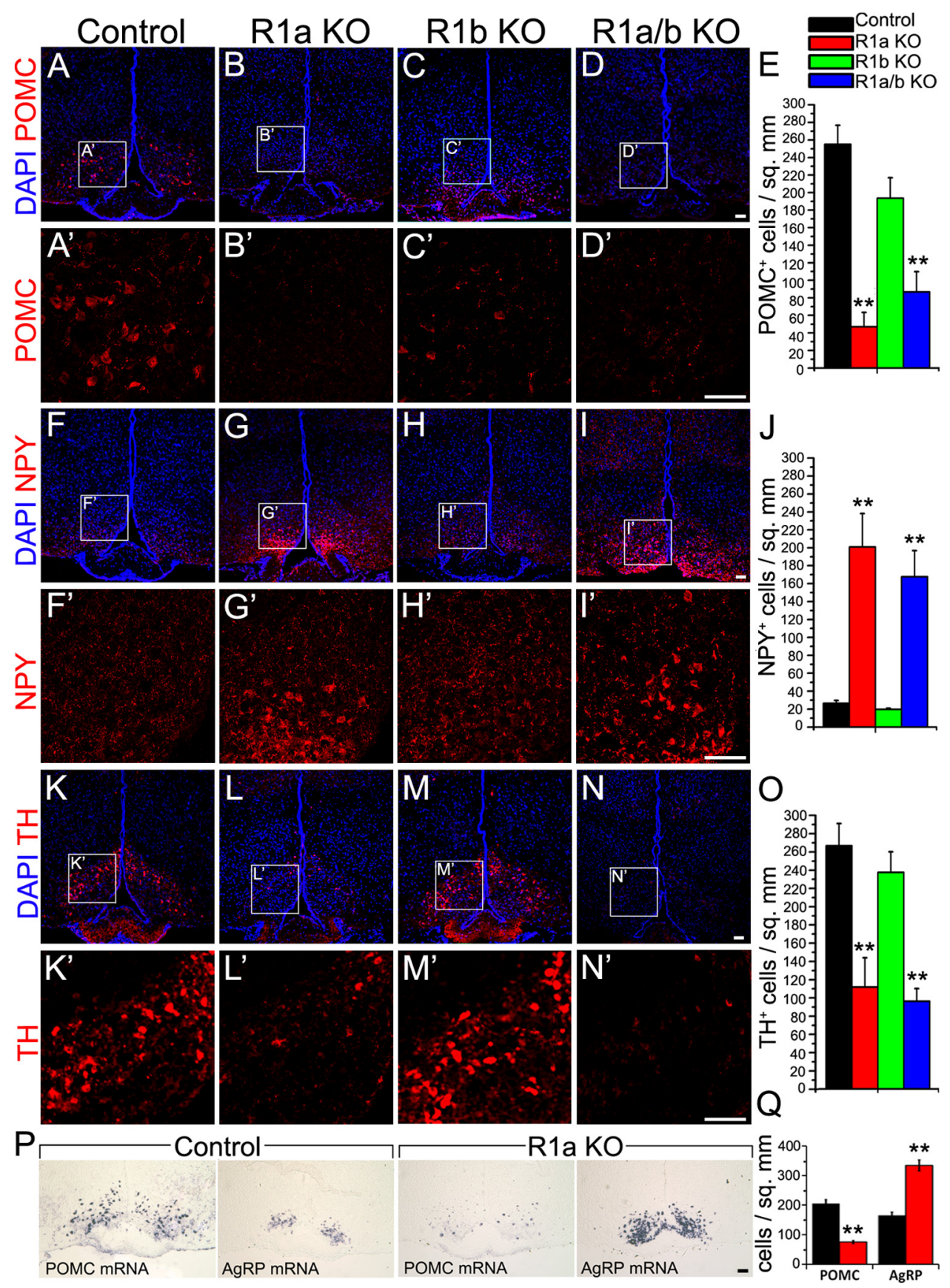

Figure 2. Hypophagia alters expression of ARH neuropeptides in Bmpr1a and Bmpr $1 a / b$ mutant mice. $A-N$, Immunofluorescent staining of melanocortin and dopaminergic system neuropeptides in the ARH of Bmpr 1 mutant mice at P21. $\boldsymbol{A}-\boldsymbol{E}, \mathrm{R} 1 \mathrm{~K}$ KO $(\boldsymbol{B}, \boldsymbol{E})$ and R1a/b KO mice $(\boldsymbol{D}, \boldsymbol{E})$ exhibit significantly reduced numbers of POMC (red) immunoreactive cell bodies in the ARH compared with control mice $(\boldsymbol{A}, \boldsymbol{E})$. DAPI-stained nuclei are in blue. $\boldsymbol{F}-\boldsymbol{J}$, There is a concomitant increase in NPY (red) immunoreactive cell bodies in R1a KO $(\boldsymbol{G}, \boldsymbol{J})$ and R1a/b K0 mice $(\boldsymbol{I}, \boldsymbol{J})$ compared with the control $(\boldsymbol{F}, \boldsymbol{J}) . \boldsymbol{K}-\mathbf{0}$, TH (red) immunoreactive cell bodies in R1a $(\boldsymbol{L}, \mathbf{0})$ and R1a/b mice $(\boldsymbol{N}, \mathbf{0})$ is significantly reduced compared with the control $(\boldsymbol{K}, \boldsymbol{N})$. $\boldsymbol{A}^{\prime}-\boldsymbol{N}^{\prime}$, Higher magnification views of the arcuate neurons. $\boldsymbol{P}$, mRNA expression analysis of POMC and AgRP by in situ hybridization in control and R1a K0 mice at P21 confirmed peptide expression changes. $\mathbf{Q}$, Quantification of POMC and AgRP mRNA-expressing cells. All data are presented as mean \pm SEM. ${ }^{* *} p<0.01$ ANOVA. Scale bars: $50 \mu \mathrm{m}$.

et al., 1995; Erickson et al., 1996; Thornton et al., 1997). To investigate if hypoglycemia in $\mathrm{R} 1 \mathrm{a} \mathrm{KO}$ mice reflected inability of ARH neurons to respond to suppressed anorexigenic signals, we first examined POMC and NPY protein expression in ARH. Consistent with lower levels of circulating leptin, we found that anorexigenic peptide POMC immunoreactivity is reduced in $\mathrm{R} 1 \mathrm{a}$ $\mathrm{KO}$ and R1a/b KO mice at P21 (Fig. 2A-E; $255.2 \pm 21.6$ cells/ $\mathrm{mm}^{2}$ for control; $47.1 \pm 16.3$ cells $/ \mathrm{mm}^{2}$ for R1a KO; $193.5 \pm$ 23.4 cells $/ \mathrm{mm}^{2}$ for $\mathrm{R} 1 \mathrm{~b} \mathrm{KO} ; 86.8 \pm 23.0$ cells $/ \mathrm{mm}^{2}$ for $\mathrm{R} 1 \mathrm{a} / \mathrm{b} \mathrm{KO}$; $p<0.01)$. We also observed a reciprocal increase of soma- localized orexigenic peptide NPY immunoreactivity in Rla KO and R1a/b KO mice at P21 (Fig. 2F-J; $26.4 \pm 3.4$ cells $/ \mathrm{mm}^{2}$ for control; $201.7 \pm 37.5$ cells $/ \mathrm{mm}^{2}$ for R1a KO; $19.7 \pm 1.3$ cells/ $\mathrm{mm}^{2}$ for $\mathrm{R} 1 \mathrm{~b} \mathrm{KO} ; 168.4 \pm 29.4$ cells $/ \mathrm{mm}^{2}$ for $\mathrm{R} 1 \mathrm{a} / \mathrm{b} \mathrm{KO} ; p<$ 0.01). A similar increase is also observed for AgRP peptide expression (data not shown; see Fig. $4 H$ ).

Since AgRP and NPY peptides are normally not enriched in the soma, quantification of immunoreactive cell bodies may be biased by detectability. To address this issue, we performed AgRP and POMC mRNA expression analysis by in situ hybridization in 
R1a KO and littermate control mice at P21. Similar to protein expression analysis, POMC mRNA-expressing cells are significantly reduced in R1a KO mice (Fig. $2 P, Q ; 205.5 \pm 12.8$ cells/ $\mathrm{mm}^{2}$ for control; $75.5 \pm 5.15$ cells $/ \mathrm{mm}^{2}$ for R1a KO; $p<0.01$ ). More importantly, examination of AgRP mRNA revealed the absolute abundance of $\mathrm{AgRP}^{+}$neurons and further confirmed an increase in both number and transcript level of AgRP in R1a KO mice (Fig. 2P, Q; $195.5 \pm 11.13$ cells $/ \mathrm{mm}^{2}$ for control; $366 \pm$ 18.43 cells $/ \mathrm{mm}^{2}$ for R1a KO; $\left.p<0.01\right)$. These changes in melanocortin pathway peptide expression are known responses to hypoglycemia, suggesting that ARH circuit appropriately suppressed anorexigenic peptide expression and upregulated orexigenic peptide expression in response to low leptin levels in R1a KO mice.

\section{Hypothalamic but not midbrain dopaminergic neurons are lost in R1a KO mice}

Hyperphagia observed in leptin mutant mice is dependent upon dopamine release (Szczypka et al., 2000). The absence of hyperphagia in response to low leptin levels in R1a KO mice suggested possible dysregulation of dopamine signaling. We therefore analyzed the ARH cell population expressing the catecholamine biosynthetic enzyme, $\mathrm{TH}$, situated dorsal to the region containing $\mathrm{POMC}^{+}$and $\mathrm{NPY}^{+}$cells (Fig. $2 \mathrm{~K}$ ), and found $\sim 58$ and 64 reductions in $\mathrm{R} 1 \mathrm{a} \mathrm{KO}$ and $\mathrm{R} 1 \mathrm{a} / \mathrm{b} \mathrm{KO}$ mice (Fig. $2 \mathrm{~K}-\mathrm{N}$; $241.6 \pm 22.1$ cells $/ \mathrm{mm}^{2}$ for control; $101.2 \pm 29.1 \mathrm{cells} / \mathrm{mm}^{2}$ for R1a KO; $215.2 \pm 20.5$ cells $/ \mathrm{mm}^{2}$ for R1b KO; $87.0 \pm 12.8$ cells/ $\mathrm{mm}^{2}$ for $\left.\mathrm{R} 1 \mathrm{a} / \mathrm{b} \mathrm{KO} ; p<0.01\right)$. Examination of TH expression in other hypothalamic nuclei also revealed reductions in the anterior preoptic nucleus (APN) and periventricular preoptic nucleus (PPN) in RH (Fig. 3A-E), but no changes in zona incerta (ZI) and dorsomedial hypothalamic nucleus (DMH) in the TuH (Fig. $3 K-$ $J$ ). In addition to the hypothalamus, loss of TH activity in dopaminergic neurons in the substantia nigra pars compacta (SNc) causes an aphagic phenotype in mice (Szczypka et al., 2001; Hnasko et al., 2006). However, immunostaining for TH at P21 shows that total dopaminergic neurons in both $\mathrm{SNc}$ and ventral tegmental area (VTA) in R1a and R1a/b KO mice did not differ from control (Fig. $3 K-R, W$ ). The presence of a ROSA ${ }^{\text {lac } Z}$ reporter in the BMPR mutant mice also allowed us to visualize OLIG1expressing cells and their progeny by $\beta$-gal immunohistochemistry. Examination of the OLIG1 lineage contribution to SNc and

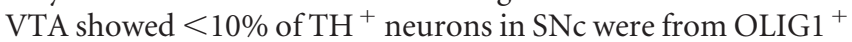
progenitors (Fig. 3S; $9.25 \pm 1.27 \%$ ), and even fewer colabeled cells were observed in VTA (Fig. $3 U ; 1.35 \pm 0.5 \%$ ). In addition, there were also no significant differences in the number of OLIG1 lineage-derived dopaminergic neurons between control (Fig. $3 S, U, M$ ) and mutant mice (Fig. $3 U, V, M$ ). Thus it is unlikely that the anorexic phenotype observed here is mediated by midbrain dopaminergic neurons.

\section{OLIG1 lineage contributes to BMPR1A-expressing ARH neuronal subtypes}

To determine whether altered BMPR function in ARH neurons contributes to the changes in neuropeptide expression observed in $\mathrm{R} 1 \mathrm{a} \mathrm{KO}$ mice, we first asked whether $\mathrm{OLIG} 1^{+}$progenitors give rise to neurons in the ARH by double immunostaining for $\beta$-gal with markers of the three ARH neuronal subtypes at E14 and P21 in the control mice. We found that a significant number of ARH neurons express $\beta$-gal at E14, including neurons that express POMC (Fig. $4 A, A^{\prime}$ ), AgRP (Fig. $4 B, B^{\prime}$ ), and TH (Fig. $4 C, C^{\prime}$ ). Since the majority of ARH neurons are born between E13 and E14 (data not shown), this finding confirms the OLIG ${ }^{+}$origin of ARH neurons. At P21, $\beta$-gal expression colocalized with all three ARH neuronal subtype markers (Fig. $4 D-F^{\prime}$ ) but with labeling of smaller percentages of ARH neurons (Fig. $4 H ; 35.38 \pm$ $3.61 \%$ of $\mathrm{AgRP}^{+}, 36.76 \pm 3.93 \%$ of $\mathrm{POMC}^{+}, 21.25 \pm 2.8 \%$ of $\mathrm{TH}^{+}$neurons express $\beta$-gal). This validates that OLIG1 ${ }^{+}$ progenitor-derived ARH neurons participate in the postnatal ARH feeding circuit, but suggests that there may also be contributions from spatially or temporally distinct progenitors other than the OLIG1 ${ }^{+}$population. Next we asked whether BMPR1A is expressed by OLIG1 ${ }^{+}$lineage-derived neurons in the ARH. Immunostaining with a BMPR1A-specific antibody in the control mice revealed a broad distribution of $\mathrm{BMPR} 1 \mathrm{~A}^{+}$cells in the ARH at P21 (Fig. 4G, $G^{\prime}$ ), including the majority of $\beta$-gal-expressing $\mathrm{OLIG}^{+}$lineage-derived neurons (Fig. $4 G, G^{\prime \prime}$, arrows). Since BMP signaling is known to regulate neural progenitor maintenance and differentiation (Gross et al., 1996; Li et al., 1998; Bonaguidi et al., 2008), we investigated whether deletion of BMPR1A alters OLIG1 ${ }^{+}$lineage contribution to the ARH neurons. Despite an increase of AgRP expression in the R1a KO (Fig. $4 I$ ), examination of $\beta$-gal ${ }^{+}$cells in the mutant and control ARH shows similar numbers and distribution at both E14 and P21 (Fig. 4I, data not shown), suggesting that changes in neuropeptide expression do not result from altered contribution of $\mathrm{OLIG}^{+}$lineage to the ARH in the absence of BMPR1A.

\section{Progenitor patterning and proliferation are unaffected in $\mathrm{R} 1 \mathrm{a}$ KO mice}

To investigate how BMP signaling affects OLIG1-derived ARH neurons during development, we first examined patterning and proliferation of neural progenitors that generate ARH neurons. In TuH, PAX6, OLIG2, and NKX2.1 transcription factors label progressively ventral progenitor domains at E13 (Fig. 5A, B). NKX2.1 is expressed in the most ventral progenitor domain that gives rise to ARH neurons (Yee et al., 2009). Although OLIG1 and OLIG2 expression typically overlap, ARH OLIG ${ }^{+}$lineage cells extend ventrally beyond the $\mathrm{OLIG}^{+}$domain and overlap with the NKX2.1 ${ }^{+}$domain (Fig. $5 A, C$, inset). These findings suggest that ARH neurons likely differentiate from NKX2.1 $1^{+} / \mathrm{OLIG}^{+}$expressing progenitors. We examined proliferation of progenitor subtypes by colabeling with the thymidine analog, EdU (Fig. $5 A, B^{\prime}$ ), and found that the number of cells double labeled with progenitor markers and EdU in R1a KO mice was comparable to the control (Fig. 5D). To investigate a possible global change in cell cycle exit, we double labeled with EdU and cell proliferation marker Ki67 to identify cells that exited cell cycle within a $24 \mathrm{~h}$ period. We found no significant changes in the total or the percentages of EdU ${ }^{+} \mathrm{Ki}^{-} 7^{-}$ cells in the ARH (Fig. $5 K$ ). These observations suggest that loss of BMPR1A signaling does not affect progenitor patterning and proliferation and cell cycle exit in the mutant hypothalamus.

\section{Differentiation of specified neuronal precursors is reduced in R1a KO mice}

Next we asked whether differentiation of ARH neurons is altered in R1a KO mice. ASCL1, a transcription factor involved in BMPmediated neuronal specification and differentiation (Lo et al., 1997; 1998; Shou et al., 1999), has been shown to regulate ARH neuron cell fate (McNay et al., 2006). We found at E13 that most $\mathrm{ASCL}^{+}{ }^{+}$cells within the ARH Nkx2.1 ${ }^{+}$domain are derived from the OLIG1 lineage, and R1a deletion did not affect the overall distribution of ASCL1 ${ }^{+}$cells (Fig. $5 E, E^{\prime}$ ). However, there was a significant reduction in ASCL1 ${ }^{+}$cell numbers in mutants (Fig. $5 G, G^{\prime}, L ; 1776.6 .16 \pm 184.05 .34$ cells $/ \mathrm{mm}^{2}$ vs control $2278.8 \pm$ 


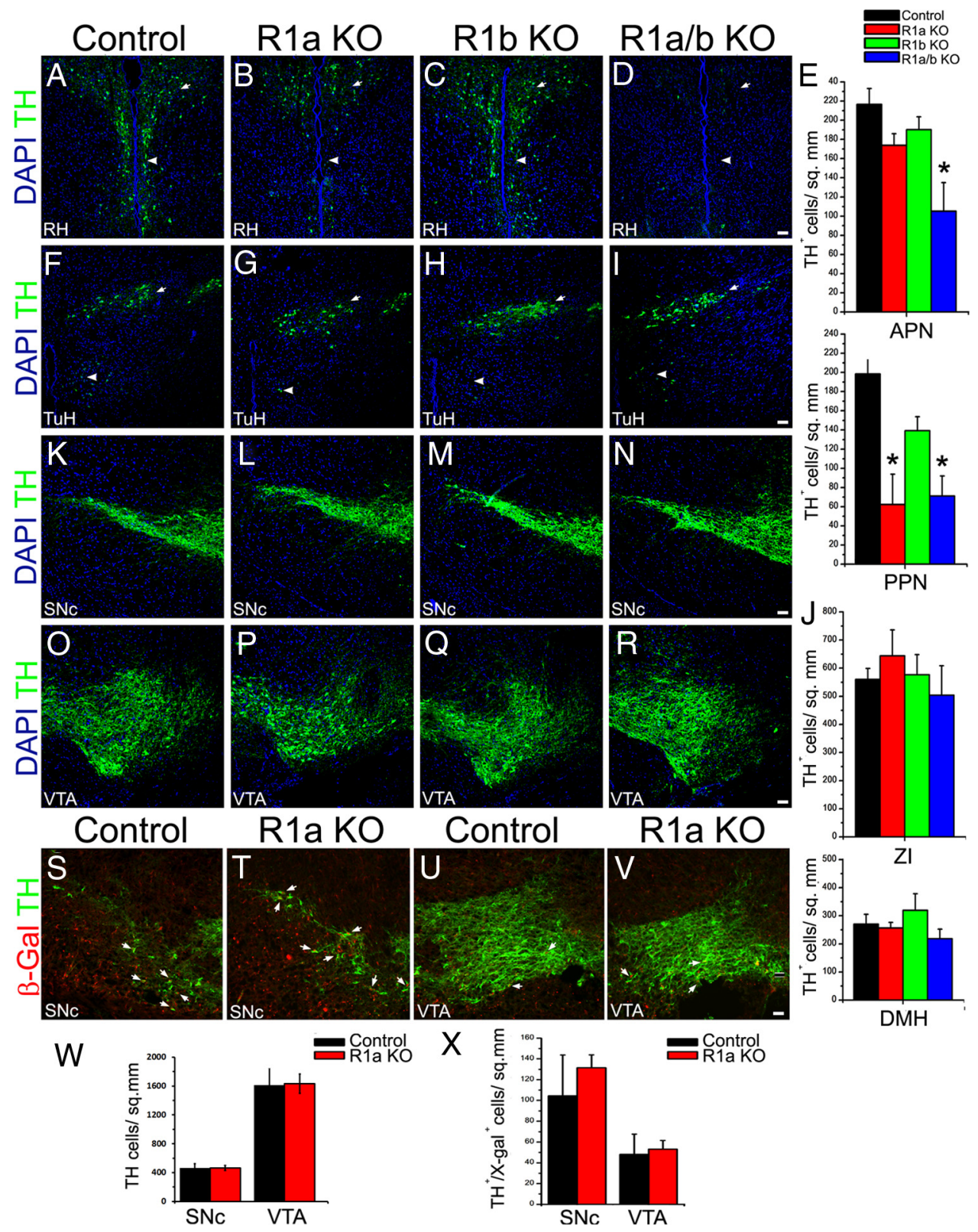

Figure 3. Loss of BMPR1A reduces the number of TH neurons in the hypothalamus but not in the midbrain. $\boldsymbol{A}-\boldsymbol{J}$, Dopaminergic neurons in the RH $(\boldsymbol{A}-\boldsymbol{D})$ and TuH $(\boldsymbol{F}-\boldsymbol{J})$ immunostained for TH (green) with DAPI-labeled nuclei in blue in P21 brain. The RH of R1a K0 mice $(\boldsymbol{B}, \boldsymbol{E})$ shows the significant reduction in number of dopaminergic neurons in the PPN (arrowheads in $\boldsymbol{A}-\boldsymbol{D})$ compared with the control $(\boldsymbol{A}, \boldsymbol{E})$ or R1b KO mice $(\boldsymbol{C}, \boldsymbol{E})$ at P21. In R1a/b KO mice $(\boldsymbol{D}, \boldsymbol{E})$ both PPN and APN (arrows in $\boldsymbol{A}-\boldsymbol{D}$ ) exhibit reduced TH expression. The DMH (arrowheads in $\boldsymbol{F}-\boldsymbol{I}$ ) in TuH and nucleus ZI (arrows in $\boldsymbol{F}-\boldsymbol{I})$ have similar numbers of dopaminergic neurons in the control $(\boldsymbol{F}, \boldsymbol{J})$, R1a KO $(\boldsymbol{G}, \boldsymbol{J}), \mathrm{R} 1 \mathrm{~b}$ KO $(\boldsymbol{H}, \boldsymbol{J})$, and R1a/b KO mice $(\boldsymbol{I}, \boldsymbol{J})$. $\boldsymbol{K}-\boldsymbol{R}$, Dopaminergic neurons in the SNc $(\boldsymbol{K}-\boldsymbol{N})$ and VTA $(\mathbf{O}-\boldsymbol{R})$ of control $(\boldsymbol{K}, \boldsymbol{O})$, R1a KO $(\boldsymbol{L}, \boldsymbol{P}), \mathrm{R} 1 \mathrm{~b}$ KO $(\boldsymbol{M}, \mathbf{Q})$, and R1a/b KO mice $(\boldsymbol{N}, \boldsymbol{R})$ immunostained for TH (green) with DAPI-stained nuclei in blue. S-V, 0 LIG1 lineage cells stained for $\beta$-gal (green) and dopaminergic neurons immunostained for TH (red) in the $\operatorname{SNc}(\boldsymbol{S}, \boldsymbol{T})$ and $\operatorname{VTA}(\boldsymbol{U}, \boldsymbol{V})$ of control $(\boldsymbol{S}, \boldsymbol{U})$ and R1a KO mice $(\boldsymbol{T}, \boldsymbol{V})$. Third ventricle is on the right. Note the small number of 0LIG1 lineage cells that express TH (arrows). $\boldsymbol{W}, \boldsymbol{X}$, Quantification of total TH neurons $(\boldsymbol{W})$ and $\beta$-gal-expressing TH neurons $(\boldsymbol{X})$ in the control and R1a K0 mice. No significant difference was observed between experimental conditions. All data are presented as mean \pm SEM Scale bars: $50 \mu \mathrm{m}$.

121.74 cells $\left./ \mathrm{mm}^{2} ; p=0.031\right)$ but no change in numbers of ASCL1 $^{+} \mathrm{EdU}^{+}$cells (Fig. $5 F, F^{\prime}, L ; 536.33 \pm 46.72$ cells $/ \mathrm{mm}^{2}$ vs control $522.41 \pm 14.89$ cells $\left./ \mathrm{mm}^{2} ; p=0.8\right)$.

There are several possible explanations for the reduction in $\mathrm{ASCL}^{+}{ }^{+}$cell numbers despite normal numbers of ASCL1 ${ }^{+} \mathrm{EdU}^{+}$ cells in R1a KO embryos. One possibility is increased apoptosis of ASCL $1^{+}$precursors. However, cleaved-caspase 3 and TUNEL staining were unchanged around the ARH (Fig. $5 \mathrm{~J}, \mathrm{~J}^{\prime}, \mathrm{K}$; data not shown). Alternatively, mutant ASCL1 ${ }^{+}$precursors may prematurely downregulate ASCL1 expression and adopt a different cell fate. The transcription factor DLX2 is expressed in the developing
ARH and maintained in some differentiated neurons (Yee et al., 2009). We found a $23 \%$ reduction of total DLX ${ }^{+}$cells in mutant ARH at E13 (Fig. $5 H, H^{\prime}, K ; 2597.53 \pm 118.8$ cells $/ \mathrm{mm}^{2}$; littermate controls: $\left.3213.54 \pm 137.22 \mathrm{cells} / \mathrm{mm}^{2} ; p=0.0057\right)$. Similar to the $\mathrm{ASCL}^{+}{ }^{+} \mathrm{ARH}$ population, numbers of dividing ( $\mathrm{EdU}^{+}$ labeled) DLX2 ${ }^{+}$cells (Fig. $5 F, F^{\prime}, K$ ) were unchanged in the mutants $\left(499.01 \pm 14.05\right.$ cells $/ \mathrm{mm}^{2}$ vs controls $502.81 \pm 14.11$ cells/ $\mathrm{mm}^{2}, p=0.21$ ). Interestingly, despite decreases in cells labeled both for DLX2 and ASCL1, there was a small but significant increase in double-labeled cells (Fig. 5M) in the mutant ARH $\left(282.08 \pm 45.4\right.$ cells $/ \mathrm{mm}^{2}$ vs controls $162.54 \pm 14.52$ cells $/ \mathrm{mm}^{2}$, 


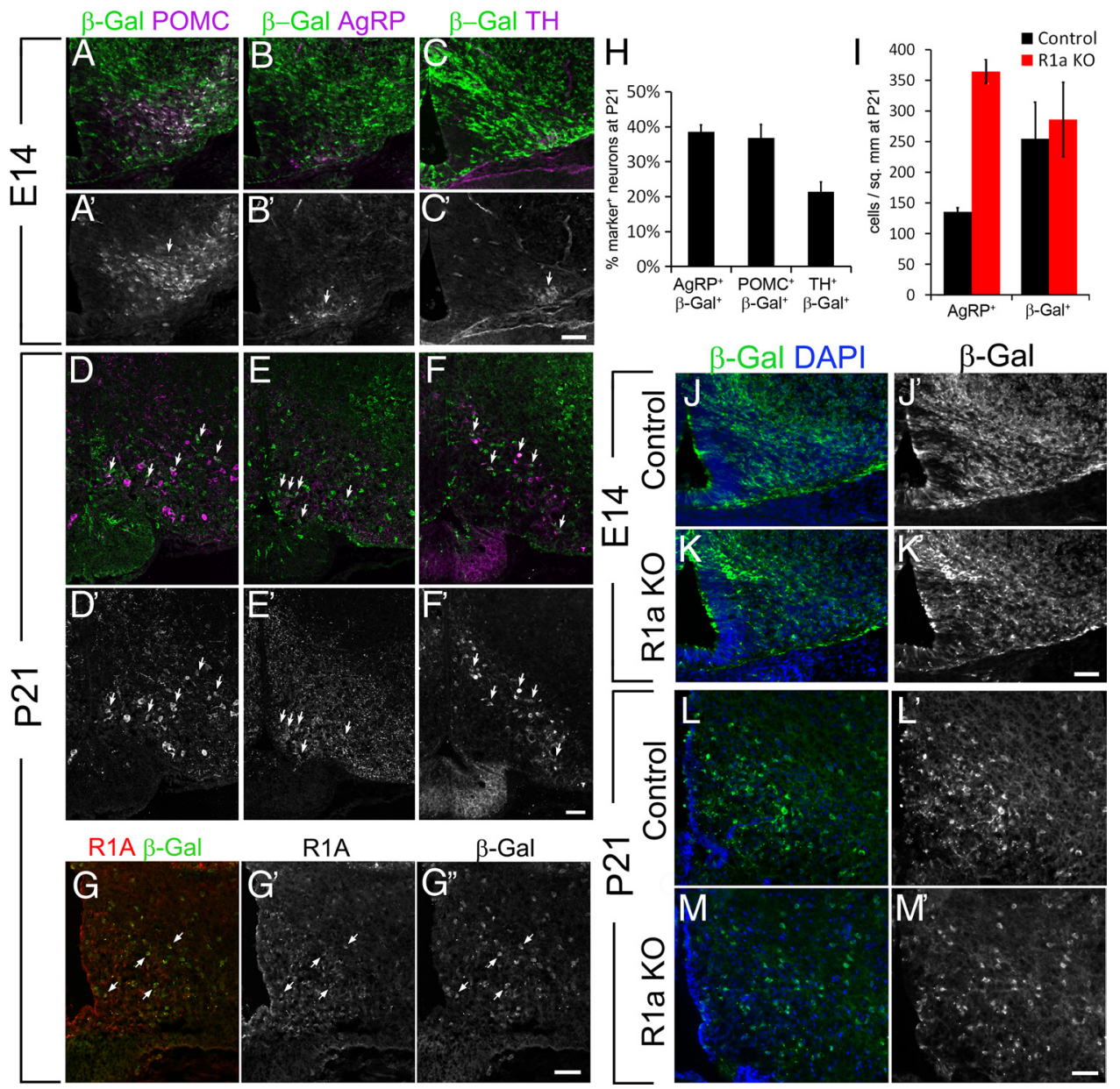

Figure 4. BMPR1A-expressing $0 L I G 1^{+}$progenitors give rise to all three neuronal subtypes of the arcuate nucleus. $A-C^{\prime}$, Hemisections of the developing ARH of $O L / G T^{c r e /+} ;$ Rosalacz/+ ${ }^{\text {mice at }}$ E14, at which time POMC $\left(\boldsymbol{A}, \boldsymbol{A}^{\prime}\right), \operatorname{AgRP}\left(\boldsymbol{B}, \boldsymbol{B}^{\prime}\right.$, arrow), and TH $\left(\boldsymbol{C}, \boldsymbol{C}^{\prime}\right.$, arrow) immunofluorescently stained neurons can be found to coexpress $\beta$-gal, suggesting that they arise from $0 \mathrm{LIG1}{ }^{+}$lineage. Third ventricle is on the left. $\boldsymbol{D}-\boldsymbol{F}^{\prime}$, Immunostaining of POMC $\left(\boldsymbol{D}, \boldsymbol{D}^{\prime}\right), \operatorname{AgRP}\left(\boldsymbol{E}, \boldsymbol{E}^{\prime}\right)$, and TH $\left(\boldsymbol{F}, \boldsymbol{F}^{\prime}\right)$ in P21 ARH also revealed double-labeled cells (arrows) but with reduced percentages. $\boldsymbol{G}-\boldsymbol{G}^{\prime \prime}$, Immunofluorescent staining of P21 ARH shows broad expression of BMPR1A (red), which can be found in $\beta$-gal ${ }^{+}$(green) $0 \mathrm{LIG1}{ }^{+}$lineage neurons (arrows, $\mathbf{G}-\boldsymbol{G}^{\prime \prime}$ ). $\boldsymbol{H}$, Quantification of the percentage of total $\mathrm{POMC}^{+}, \mathrm{AgRP}^{+}$, and TH ${ }^{+}$neurons that express $\beta$-gal in P21 ARH. $I$, Quantification of AgRP ${ }^{+}$and $\beta$-gal ${ }^{+}$neurons in the control and R1a KO mice. J-M $\left.M^{\prime}\right) \beta$-gal ${ }^{+}$neuron (green) distribution does not differ significantly in the control $\left(\boldsymbol{J}, \boldsymbol{J}^{\prime}, \boldsymbol{L}, \boldsymbol{L}^{\prime}\right)$ and mutant $\left(\boldsymbol{K}, \boldsymbol{K}^{\prime}, \boldsymbol{M}, \boldsymbol{M}^{\prime}\right)$ ARH at E14 and P21. Values are presented as mean $\pm \mathrm{SEM},{ }^{* *} p<0.01$. Scale bars: $50 \mu \mathrm{m}$.

$p=3.92$ E06). The majority of $\mathrm{DLX}_{2}{ }^{+} \mathrm{ASCL}^{+}{ }^{+}$cells do not colabel with EdU (Fig. 5M) but reside within the subventricular zone, suggesting that they may be transient precursors that exited cell cycle but failed to further differentiate in the absence of BMPR1A.

\section{ARH neurons in R1a KO mice show altered embryonic cell fate specification}

ASCL1 and DLX2 both promote GABAergic cell fate commitment in ventral telencephalon (Anderson et al., 1997; 1999; Letinic et al., 2002; Stühmer et al., 2002; Long et al., 2009), a process that is also known to be regulated by BMP signaling (Yung et al., 2002; Gulacsi and Lillien, 2003; Samanta et al., 2007; Mukhopadhyay et al., 2009). Since DLX2 ${ }^{+}, \mathrm{AgRP}^{+}$, and $\mathrm{TH}^{+}$ neurons in the ARH all express GAD67 at birth (Yee et al., 2009), we hypothesized that loss of BMPR1A signaling with the resultant decrease in numbers of ASCL1 and DLX2 neuronal precursors would affect specification of these three ARH neuronal subtypes. We therefore examined the development of DLX2 ${ }^{+}, \mathrm{AgRP}^{+}$, and $\mathrm{TH}^{+}$neurons in the ARH by immunohistochemistry and quantified cell numbers at E14, E17, P0, P7, and P14. We found that in the embryonic ARH, DLX2 and AgRP are expressed by distinct neuronal populations that show opposing changes in cell num- bers in R1a KO mice (Fig. $6 A, B, E^{\prime}, F^{\prime}, H^{\prime}$ ). Specifically, DLX2 ${ }^{+}$ neurons at E14 are significantly reduced in R1a KO mice (Fig. 7A, $E^{\prime \prime}, H^{\prime} ; 1257 \pm 32$ cells $/ \mathrm{mm}^{2}$; controls: $1545.42 \pm 33.11$ cells/ $\left.\mathrm{mm}^{2}, p=4.57 \mathrm{E} 05\right)$, whereas $\mathrm{AgRP}^{+}$neurons are slightly increased (Fig. $6 B, F^{\prime}, H^{\prime} ; 196.06 \pm 11.66$ cells $/ \mathrm{mm}^{2}$; controls: $154.07 \pm 13.97$ cells $\left./ \mathrm{mm}^{2} ; p=0.046\right)$. In contrast, $\mathrm{TH}^{+}$neurons in E14 ARH are found to always coexpress DLX2, but cell numbers in R1a KO mice are comparable to the control (Fig. $6 C, G^{\prime}, H^{\prime} ; 203.02 \pm 27.54$ cells $/ \mathrm{mm}^{2}$, control: $197.33 \pm 6.88$ cells $\left./ \mathrm{mm}^{2}, p=0.85\right)$, suggesting that the observed reduction in DLX2 expression is restricted to $\mathrm{TH}^{-}$neurons. Similar cell number changes are observed for all three neuronal subtypes at E17 (Fig. 6A, $B, C$; data not shown). These findings confirm that BMPR1A is necessary for the initial differentiation and specification of ARH neuronal subtypes during embryonic development.

\section{ARH neurons in R1a KO mice have different postnatal neuropeptide properties}

Postnatally, changes in DLX2 ${ }^{+}$and $\mathrm{AgRP}^{+}$neuron numbers observed in R1a KO embryos are no longer present at P0 and P7 (Fig. 6A, $B$; data not shown). However, a significant increase of DLX2 ${ }^{+}$neurons is found at P14 in the ARH of R1a KO mice (Fig. $6 I ; 1252.27 \pm 55.24$ cells $/ \mathrm{mm}^{2}$, control: $694.44 \pm 29.27$ cells/ 
$\left.\mathrm{mm}^{2} ; p=2.29 \mathrm{E} 8\right)$, along with a small increase of $\mathrm{AgRP}^{+}$neurons (Fig. 6J; $197.32 \pm 15.18$ cells $/ \mathrm{mm}^{2}$; control: $137.15 \pm 7.59$ cells $\left./ \mathrm{mm}^{2} ; p=0.023\right)$. In contrast to their opposing embryonic expression, most $\mathrm{AgRP}^{+}$neurons at $\mathrm{P} 14$ also expressed DLX2 (Fig. 6D, L; $139.45 \pm$ 7.02), and numbers of $\mathrm{AgRP}{ }^{+} / \mathrm{DLX}^{+}$ cells were increased in Rla KO mice (Fig. $6 D^{\prime}, L, 197.32 \pm 23.03$; $\left.p=0.026\right)$. In addition to changes in cell number, we also observed a change in AgRP protein distribution where fibrous staining found in the control is significantly reduced in mutant, accompanied by elevated soma staining intensity (Fig. 6J, J'). Surprisingly, postnatal $\mathrm{TH}^{+}$neuron numbers were similar in R1a KO and control ARH at all time points analyzed except at P21 when they were reduced (Fig. $6 C, K, K^{\prime}$ ). Although total $\mathrm{TH}^{+}$neuron numbers were unaffected at P14, the number of $\mathrm{TH}^{+} / \mathrm{DLX}_{2}{ }^{+}$double-labeled cells significantly increased in R1a $\mathrm{KO}$ mice (Fig. $6 D, L, L^{\prime} ; 225.78 \pm 9.16$; control: $143.25 \pm$ $11.51 ; p=7.72$ E05). Since DLX2 function is correlated with GABAergic cell fate specification, increased DLX2 expression in AgRP and TH in Rla KO mice supporting the idea that ARH neurons may acquire more inhibitory characteristics in the absence of BMPR1A signaling.

\section{BMPR1A signaling is necessary for} postnatal ARH neurite outgrowth To investigate how BMP signaling regulates the postnatal establishment of $\mathrm{ARH}$ circuits, we focused on developmental events transpiring when weight loss in $\mathrm{R} 1 \mathrm{a}$ $\mathrm{KO}$ mice is first observed. ARH neurons project to target nuclei during $\mathrm{P} 6$ and $\mathrm{P} 12$, during which time circulating leptin is elevated and necessary to promote axonal growth (Ahima et al., 1998; Bouret et al., 2004). Since this correlates temporally with the onset of weight loss in $\mathrm{R} 1 \mathrm{a} \mathrm{KO}$ mice, we asked whether ARH neurons project to appropriate targets in the mutants. Since AgRP ${ }^{+}$cell bodies are only found in the ARH, fiber-associated AgRP expression in ARH target nuclei was used as an indicator of ARH-originated neuronal projections. $\mathrm{AgRP}^{+}$fibers in $\mathrm{R} 1 \mathrm{a} \mathrm{KO}$ mice (Fig. $7 A^{\prime \prime}$ ) were greatly reduced at P21 in DMH (Fig. $7 A-A^{\prime \prime}$ ), the earliest target of ARH projections, despite increased expression in cell bodies (Fig. 7A, arrows). Similarly, AgRP expression in the PVH (Fig. $7 B-B^{\prime \prime}$ ), an essential component of the hypothalamic feeding circuit, was drastically reduced (Fig. $\left.7 B^{\prime \prime}\right) . \mathrm{TH}^{+}$fibers were also reduced in $\mathrm{DMH}$ and $\mathrm{PVH}$, consistent with the loss of $\mathrm{TH}^{+}$cell bodies in R1a KO ARH (Fig. $7 A, B$ ). In addition, the loss of $\mathrm{POMC}^{+}$cell bodies in $\mathrm{R} 1 \mathrm{a} \mathrm{KO} \mathrm{ARH}$ resulted
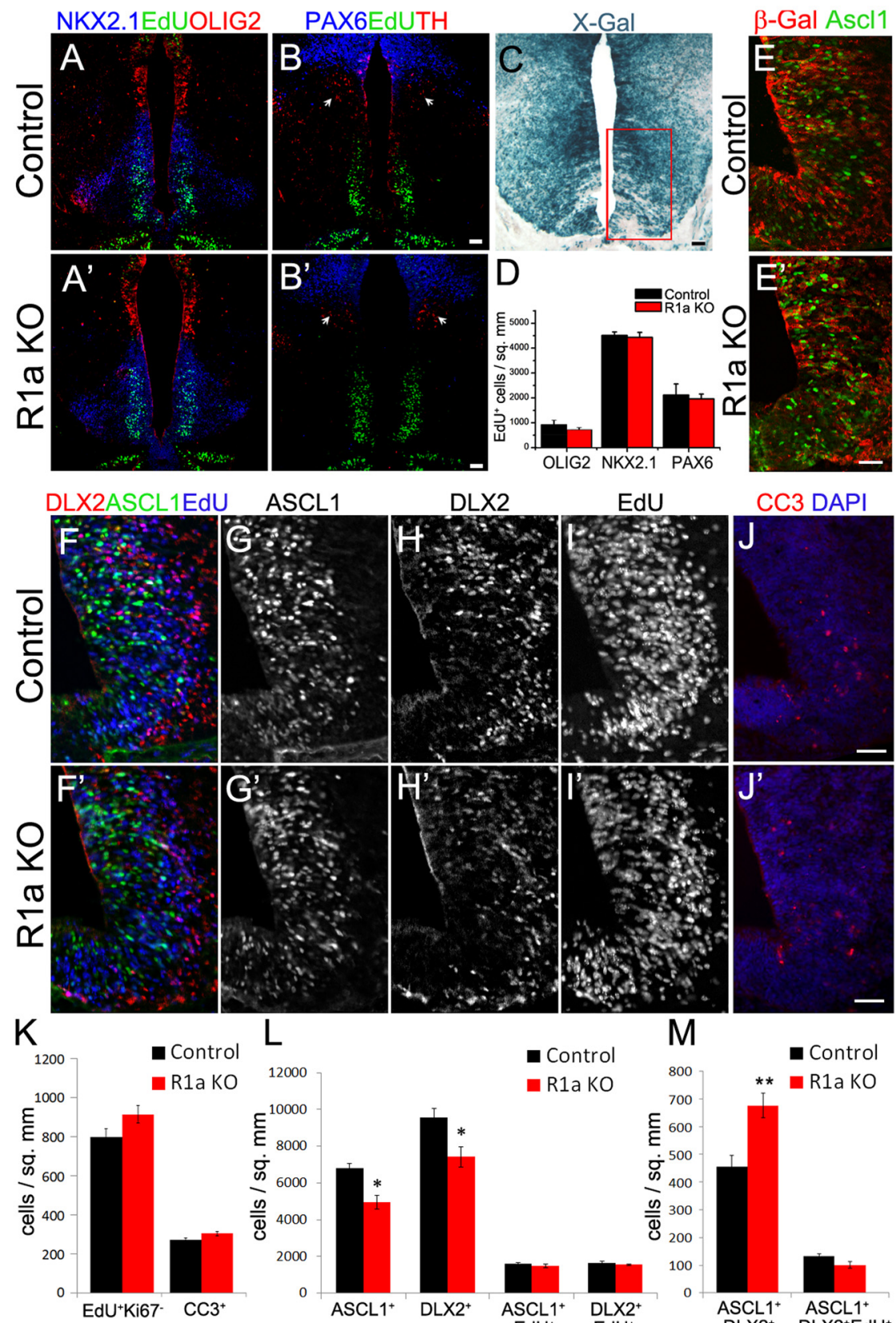

EdU

CC3 DAPI

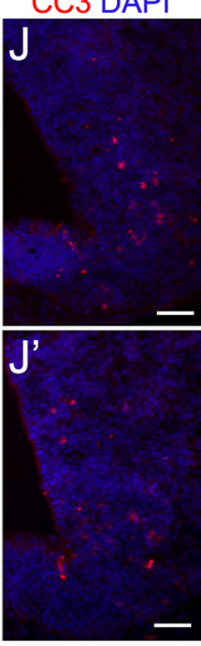

Figure 5. Loss of BMPR1Aleads to a reduction of differentiating $\mathrm{ASCL}_{1}{ }^{+}$andDLX2 ${ }^{+}$neuronal precursors but does not affect the proliferation of neural progenitors in the developing ARH. $A$, E13 TuH of control ( $A$ ) and R1a ( $\boldsymbol{A}^{\prime}$ ) mice immunostained for Nkx2.1 (blue), Olig2 (red), and EdU (green). $\boldsymbol{B}, \mathrm{E} 13 \mathrm{TuH}$ of control (B) and R1a KO ( $\boldsymbol{B}^{\prime}$ ) mice for Pax6 (blue), TH (red), and EdU (green). Note the $\mathrm{TH}^{+}$cells (arrow) in the developing Zl in the TuH. C, OLIG1 lineage cells in the control mice detected by X-gal (blue) staining. Red inset box delineates Nkx2.1 + region that is selected for subsequentimaging and cell count analysis. D, Quantification of proliferating $\left(\mathrm{EdU}^{+}\right)$progenitors that express Nkx2.1, 0lig2, and Pax6 in E13 ARH of control (black) and R1aKO mice (red). No significant differenceinEdUlabeling was detected in all threeprogenitorsubtypes.E, $\beta$-Gal (red) and ASCL1 (green) expression in the NKX2.1 domain ofE13 ventral hypothalamus. Majority of ASCL1-expressing cells coexpress $\beta$-gal, suggesting that they are 0LIG1 lineage-derived. $\boldsymbol{F}-\boldsymbol{I}^{\prime}$, Representative micrograph of the ARH atE13, immunostained with ASCL1 (red, $\left.\boldsymbol{F}, \boldsymbol{F}^{\prime}, \mathbf{G}, \boldsymbol{G}^{\prime}\right), \mathrm{DLX} 2$ (green, $\boldsymbol{F}, \boldsymbol{F}^{\prime}, \boldsymbol{H}, \boldsymbol{H}^{\prime}$ ), and EdU (blue, $\left.\boldsymbol{F}, \boldsymbol{F}^{\prime}, \boldsymbol{I}, \boldsymbol{I}^{\prime}\right) . \boldsymbol{J}, \boldsymbol{K}, \mathbf{E}$ Expression of cleaved-caspase3 (CC3, red) and DAPI (blue) inE13 control (J) and R1a KO (J') ARH. $\boldsymbol{K}$, Quantification of total EdU ${ }^{+} \mathrm{Ki}_{67}{ }^{-}$cells and $\mathrm{CC}^{+}$cells in E13 ARH suggest no changes in cell cycle exit and apoptosis. L, Quantification of total cell numbers in the Nkx.2.1 domain that are $\mathrm{ASCl}_{1}{ }^{+}, \mathrm{DLX2}^{+}, \mathrm{ASCL}^{+} \mathrm{EdU}^{+}$, and DLX2 ${ }^{+} \mathrm{EdU}{ }^{+}$in the $\mathrm{E} 13 \mathrm{ARH}$ of control and R1a KO mice. Reduction of total ASCL1- and DLX2-expressing cells is found in the R1a KO ARH. $M$, Quantification of total number of cells that are ASCL1 ${ }^{+} \mathrm{DLX}_{2}{ }^{+}$and $\mathrm{ASCL}^{+}{ }^{+} \mathrm{DLX2}{ }^{+} \mathrm{EdU}^{+}$. An increase number of $\mathrm{ASCL} 1^{+} \mathrm{DLX2}{ }^{+}$cells are observed in the R1a KO ARH. All data are presented as mean \pm SEM. ${ }^{*} p<0.05 ;{ }^{* *} p<0.01$. Scale bars: $50 \mu \mathrm{m}$.

in fewer fibers expressing $\alpha \mathrm{MSH}$ in $\mathrm{PVH}$, where the receptor MC4R resides and remains intact in mutants (Fig. $7 C-C^{\prime \prime}$ ). Together, these findings suggest that the leptin-mediated orexigenic signaling which increased AgRP expression in the ARH was 

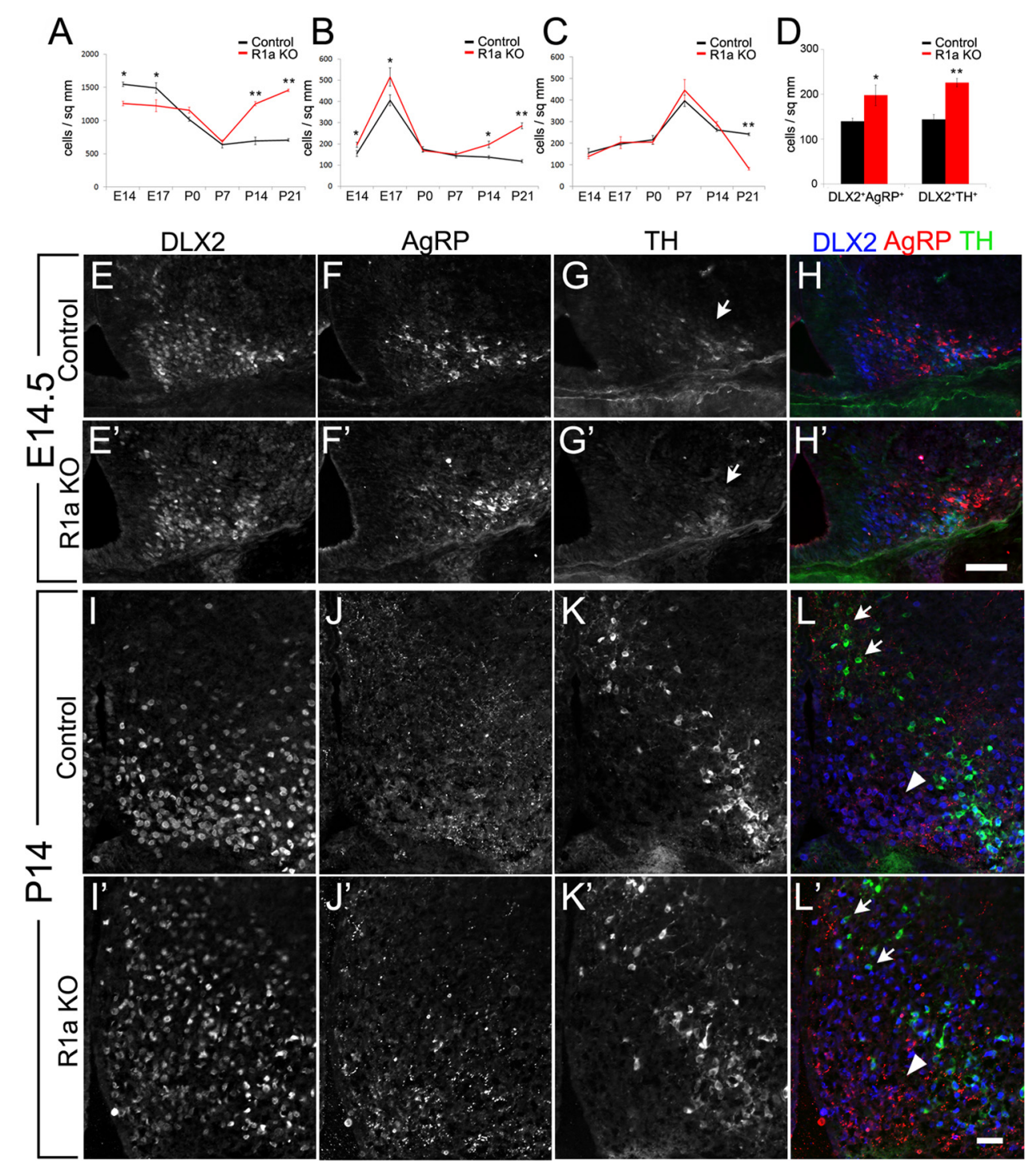

Figure 6. Developmental expression analyses of DLX2, AgRP, and TH highlights BMPR1A function in the postnatal ARH development. $\boldsymbol{A}-\boldsymbol{C}$, Quantification of DLX2 (A), AgRP $(\boldsymbol{B})$, and TH $(\boldsymbol{C})$ expressing neurons in control (black lines) and R1a KO (red lines) mice at multiple developmental time points. D, Quantification of DLX2 ${ }^{+} / \mathrm{AgRP}^{+}$and DLX2 $^{+} / \mathrm{TH}^{+}$ARHs at P14. (E-H', ARH in E14.5 control and R1a K0 embryos immunostained for DLX2 $\left(\boldsymbol{E}, \boldsymbol{E}^{\prime}\right), \operatorname{AgRP}\left(\boldsymbol{F}, \boldsymbol{F}^{\prime}\right)$, and TH $\left(\boldsymbol{G}, \boldsymbol{G}^{\prime}\right)$. Triple immunostaining of DLX2 (blue), AgRP (red), and TH (green) shows complete colocalization of DLX2 and TH and lack of colocalization of DLX2 and AgRP in E14.5 control $(\boldsymbol{H})$ and R1a KO $\left(\boldsymbol{H}^{\prime}\right)$. (I- $\left.\boldsymbol{L}^{\prime}\right)$ ARH in P14 control and R1a KO mice immunostained for DLX2 $\left(\boldsymbol{I}, \boldsymbol{I}^{\prime}\right), \operatorname{AgRP}\left(\boldsymbol{J}, \boldsymbol{J}^{\prime}\right)$, and TH $(\boldsymbol{K}$, $\left.\boldsymbol{K}^{\prime}\right)$. Triple immunostaining of DLX2 (blue), AgRP (red), and TH (green) shows increased DLX2 and AgRP expression leading to more DLX2 ${ }^{+} \mathrm{AgRP}^{+}\left(\boldsymbol{L}\right.$, arrowheads) and DLX2 ${ }^{+} \mathrm{TH}^{+}(\boldsymbol{L}$, arrows) neurons in R1a KO $\left(\boldsymbol{L}^{\prime}, \boldsymbol{D}\right)$ compared with control mice $(\boldsymbol{L}, \boldsymbol{D}) . n \geq 3$ per time point. Values are presented as mean \pm SEM, ${ }^{*} p<0.05 ;{ }^{* *} p<0.01$. Scale bars: $50 \mu \mathrm{m}$.

unable by itself to enable ARH neurons to project to targets necessary to promote feeding in Rla KO mice.

We therefore asked whether BMP signaling is necessary for ARH neurons to extend neurites in response to leptin. We microdissected the ARH from P7 hypothalamus and cultured it with vehicle, leptin, or leptin plus the BMP antagonist noggin for $72 \mathrm{~h}$. Leptin treatment significantly increased the number of neurites extending from explants (Fig. $7 D, E$; leptin treatment sample fiber density $=59.28 \pm$ 6.53; vehicle treatment sample fiber density: $12.51 \pm 2.05$; $p=$ $0.014)$. However, leptin-induced neurite outgrowth was profoundly inhibited by noggin (fiber density $=15.27 \pm 2.81 ; p=0.016$ ). Interestingly, when long neurites were occasionally observed in noggin-treated explants, they had markedly reduced branching (Fig. $7 D)$. To examine specifically whether BMPR1A participates the leptin-induced neurite outgrowth, we cultured ARH explants from P7 R1a KO mice and littermate control mice with leptin, and observed a similar reduction of neurite outgrowth in R1a KO ARH explants (Fig. $7 F, G$; control fiber density $=80.04 \pm 11.45$; Rla KO fiber density $=26.55 \pm 6.29 ; p=0.004$ ). These findings suggest that BMP signaling is necessary for the leptin-induced neurite outgrowth from ARH neurons during the onset of establishment of feeding circuits.

Phosphorylation of signal transducer and activator of transcription-3 (STAT3) mediates leptin-regulated adult feeding behavior in the adult (Vaisse et al., 1996; Bates et al., 2003; Xu et al., 2007) as well as postnatal development of ARH circuits (Bouret et al., 2012). Additional signaling cascades, including phosphorylation of mitogen-activated protein kinase and phosphatidylinositol 3 kinase, are responsive to leptin receptor activation (Niswender et al., 2001; Bouret et al., 2012). To determine the effect of leptin on BMP signaling during the period of hypothalamic feeding circuit establishment, we injected leptin into P7 wild-type mice and examined BMP signaling activation via phospho-SMAD 1/5/8 (pSMAD) immunostaining. The efficacy 

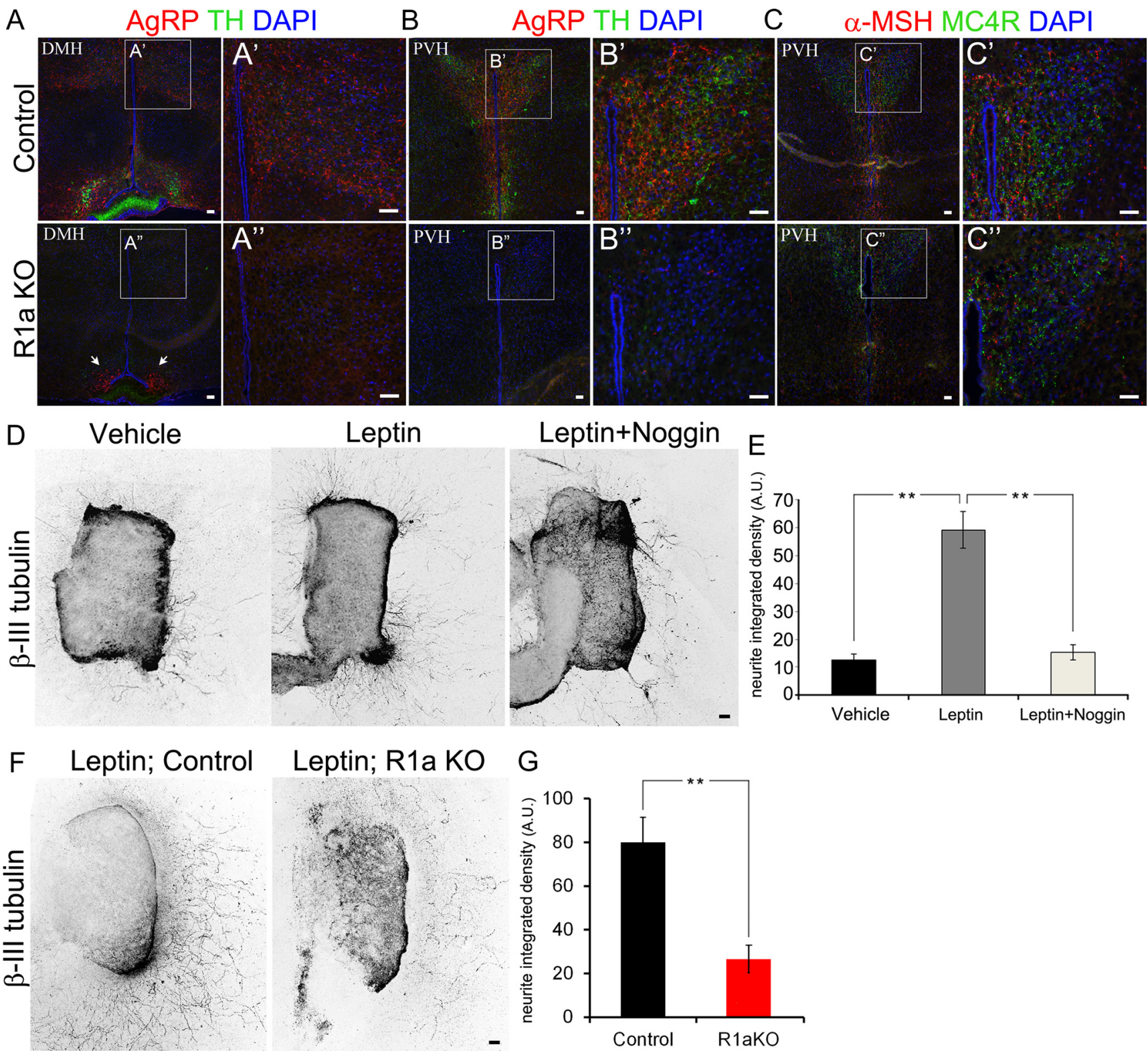

Figure 7. BMP signaling is necessary for neurite outgrowth of the ARH neurons. $A-\boldsymbol{B}^{\prime \prime}, \mathrm{AgRP}\left(\right.$ red) and TH (green) expression in ARH target nuclei DMH $\left(\boldsymbol{A}-\boldsymbol{A}^{\prime \prime}\right)$ and PVH $\left(\boldsymbol{B}-\boldsymbol{B}^{\prime \prime}\right)$ in P21 control $\left(\boldsymbol{A}^{\prime}\right.$, $\left.\boldsymbol{B}^{\prime}\right)$ and R1a KO $\left(\boldsymbol{A}^{\prime \prime}, \boldsymbol{B}^{\prime \prime}\right)$ hypothalamus. Greatly reduced AgRP ${ }^{+}$and TH ${ }^{+}$fibers are detected in both target nuclei. $\boldsymbol{C}, \alpha$-MSH (red) and MC4R (green) expression in PVH of P21 control ( $\left.\boldsymbol{C}^{\prime}\right)$ and R1a KO $\left(\boldsymbol{C}^{\prime}\right)$ hypothalamus. A reduction of $\alpha$-MSH expression is observed in the R1a KO PVH but MC4R expression is comparable between mutant and control mice. $\boldsymbol{D}$, Representative micrograph of P7 wild-type ARH explant culture treated with vehicle, leptin $(100 \mathrm{ng} / \mathrm{ml})$, and leptin plus noggin $(250 \mathrm{ng} / \mathrm{ml})$ after $3 \mathrm{~d}$ in vitro. Extensive neurites outgrowth, represented by $\beta$-III tubulin immunostaining away from the tissue (black), is visible in leptin-treated group but much fewer in the vehicle control and Noggin-treated samples. $\boldsymbol{E}$, Quantification of extended neurite-specific integrated density in ARH explants treated with vehicle control, leptin, and leptin plus noggin. $F$, ARH explants from control and R1a K0 mutant mice cultured in the presence of leptin-confirmed reduced neurite outgrowth in BMP signaling impaired condition. G, Quantification of integrated density in control and R1a KO mutant ARH explants. $n=6-8$ per condition. Values are presented as mean \pm SEM, ${ }^{*} p<0.01$, ANOVA. Scale bars: $50 \mu \mathrm{m}$.

of the leptin injection was confirmed by the increased number of phospho-STAT3 (pSTAT3)-expressing ARH neurons at $45 \mathrm{~min}$ postinjection, with many $\mathrm{AgRP}^{+}$neurons expressing pSTAT3 (data not shown). In the vehicle-injected controls pSMADexpressing $\left(\mathrm{pSMAD}^{+}\right)$cells were found sparsely distributed across the ventral hypothalamus, including the ARH. However, the number of $\mathrm{pSMAD}^{+}$cells in the ventral hypothalamus, including the ARH, increased significantly at $45 \mathrm{~min}$ postleptin injection (Fig. $8 A, B$; vehicle $=103.72 \pm 7.95$ cells $/ \mathrm{mm}^{2}$; leptin + $45 \mathrm{~min}=158.75 \pm 11.57$ cells $/ \mathrm{mm}^{2} ; p=4.43$ E05). Total pS$\mathrm{MAD}^{+}$cell numbers returned close to the control levels at $3 \mathrm{~h}$ postleptin injection, suggesting that the effect of leptin on overall
pSMAD activation is transient. Interestingly, detailed examination of pSMAD expression in $\mathrm{AgRP}^{+}$neurons in the ARH revealed a small but significant increase at $3 \mathrm{~h}$ after leptin injection (Fig. $8 A$, inset, $C$; vehicle $=11.38 \pm 1.98$ cells $/ \mathrm{mm}^{2}$; leptin $+3 \mathrm{~h}$ $=24.87 \pm 3.61$ cells $/ \mathrm{mm}^{2} ; p=0.002$ ). These findings suggest that in addition to STAT3 pathway activation, leptin also promotes both short- and long-term activation of BMP signaling during the development of feeding circuits in the ARH.

\section{Discussion}

We find that conditional ablation of BMPR1A in the OLIG1 lineage causes severe preweaning anorexia in mice. Genetic muta- 
A

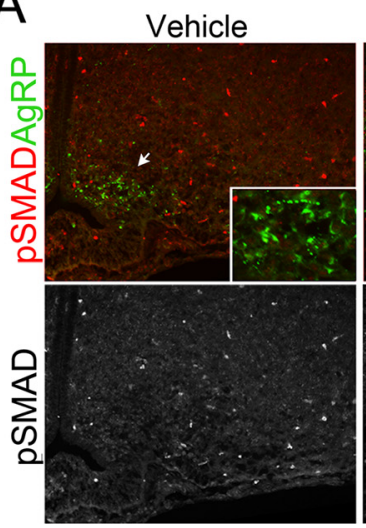

Leptin $45 \mathrm{~min}$

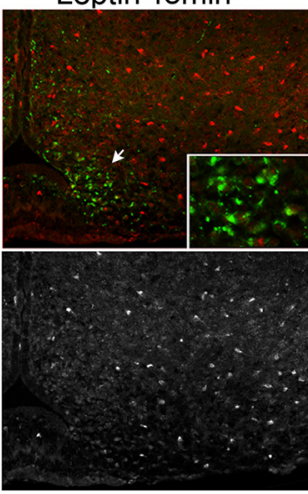

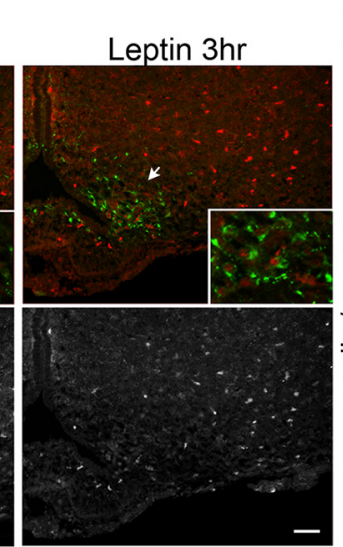
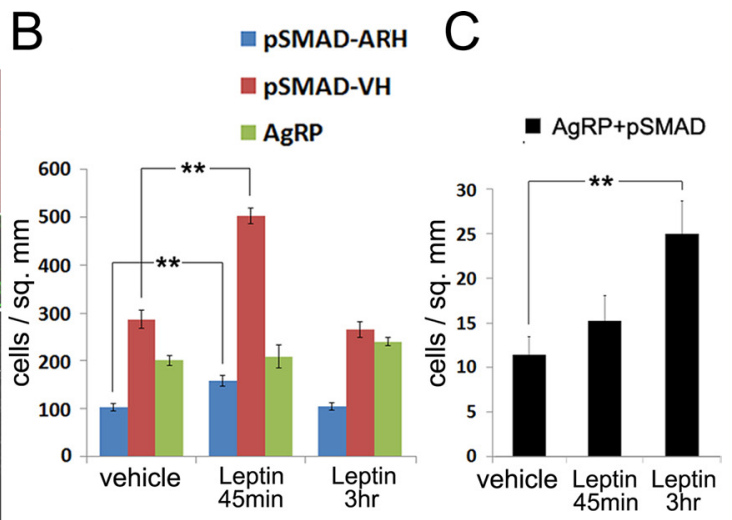

Figure 8. Leptin-induced activation of BMP signaling in the ARH. $A$, Immunofluorescent staining of pSMAD1/5/8 (red) in ventral hypothalamus at 45 min and $3 \mathrm{~h}$ after leptin injection compared with vehicle-injected control. Increased colocalization of pSMAD with AgRP ${ }^{+}$neurons (green, arrows and inset) is observed at $3 \mathrm{~h}$ postleptin injection. $\boldsymbol{B}, \mathrm{Quantification}$ of $\mathrm{pSMAD}{ }^{+}$cells in ventral hypothalamus (pSMAD-VH) and arcuate nucleus (pSMAD-ARH) at indicated time points with AgRP neuron cell counts. C, Quantification of AgRP ${ }^{+} /$pSMAD ${ }^{+}$cells in the ARH shows significant increase in double-labeled cells at $3 \mathrm{~h}$ postleptin injection compared with vehicle-injected control. $n=4$ per condition. Values are presented as mean \pm SEM, ${ }^{* *} p<0.01$. Scale bar, $50 \mu \mathrm{m}$.

tions previously known to cause anorexia in mice close to weaning include mutations in contactin, anorexic (anx) gene product and Th (Maltais et al., 1984; Zhou and Palmiter, 1995; Berglund et al., 1999). Contactin mutant mice appear anorexic and have increased NPY and AgRP expression in ARH similar to Rla KO mice (Berglund et al., 1999; Fetissov et al., 2005). However, contactin mutant mice exhibit severe ataxia $\sim \mathrm{P} 10$ that may lead to anorexia (Berglund et al., 1999). Unlike contactin mutants, Rla KO mice do not exhibit motor deficits, suggesting dissimilar mechanisms underlying the anorexic phenotype. Anx/ anx and Th mutant mice exhibit phenotypes more similar to R1a KO. Anx/anx mice begin losing weight around the same time, and show similar reductions in serum leptin levels and changes in hypothalamic NPY and POMC expression (Johansen et al., 2003). Ablation of TH specifically in dopaminergic neurons causes an anorexic phenotype with a time line similar to R1a KO mice (Zhou and Palmiter, 1995), which prompted us to investigate dopaminergic neurons in $\mathrm{R} 1 \mathrm{a} \mathrm{KO}$ mice. There were no changes in dopaminergic neuron numbers in SNc or VTA, most likely due to the very limited contribution from OLIG $1^{+}$lineage to these nuclei.

We also examined the possibility that dopamine dysregulation in the hypothalamus might lead to the anorexic phenotype, as it has been shown that dopamine signaling increases feeding in the medial hypothalamus and inhibits feeding in the lateral hypothalamus (Robert et al., 1990; Fetissov et al., 2000). Based on $\mathrm{TH}$ expression, we found that ARH dopaminergic neurons are born and can survive past 2 weeks after birth in R1a KO mice. However, an increased percentage of $\mathrm{TH}^{+}$neurons at P14 express DLX2, a transcription factor that promotes GABAergic traits. This suggests that despite normal TH expression, alterations in other neurotransmitters in $\mathrm{R} 1 \mathrm{a} \mathrm{KO}$ mutants could affect how dopaminergic neurons function in neural circuits. We also observed a reduction of $\mathrm{ARH} \mathrm{TH}^{+}$neurons at P21 in $\mathrm{R} 1 \mathrm{a} \mathrm{KO}$ mice. However, loss of ARH dopaminergic neurons is likely not the cause of hypophagia, since R1a KO mice stop gaining weight at $\mathrm{P} 14$ when $\mathrm{TH}^{+}$neuron numbers were unchanged. Furthermore, loss of ARH dopaminergic neurons has been observed in $D l x 1$ and Six 6 mutant mice, which are both viable into adulthood (Yee et al., 2009; Larder et al., 2011). Thus changes in dopaminergic neurons in ARH could contribute to, but are not primarily responsible for, the anorexic phenotype in R1a KO mice.
Oligodendrocytes and somatic motor neurons arise from the $\mathrm{OLIG1}^{+}$lineage (Zhou et al., 2000; Lu et al., 2002). Mice mutant for Bmprla in the OLIG ${ }^{+}$lineage have increased numbers of oligodendrocytes but no changes in spinal motor neurons (Samanta et al., 2007). The increased number of oligodendrocytes is unlikely to cause a hypophagic phenotype as most oligodendrocytes in postnatal brain are derived from an EMX1 ${ }^{+}$ lineage (Kessaris et al., 2006) and mice carrying Bmprla mutations in the $\mathrm{EMX} 1^{+}$lineage are not hypophagic and are viable (Yuhki et al., 2004). In hindbrain, the OLIG1 ${ }^{+}$lineage contributes to hypoglossal neurons that innervate the tongue, but we found no changes in neuron numbers in the hypoglossal nucleus (data not shown). Further, mice with deletion of Bmprla in the $\mathrm{HB}^{+}{ }^{+}$lineage that generates all somatic motor neurons are viable into adulthood (E. Laufer, personal communication). Thus loss of BMPR1A function in somatic motor neurons, including hypoglossal neurons, does not underlie the hypophagia.

Cholinergic neurons of the basal forebrain $(\mathrm{BFCN})$ are also generated from OLIG1/2 ${ }^{+}$lineage precursors and cholinergic neuron differentiation is affected in OLIG2 mutant brains (Furusho et al., 2006). Moreover, cholinergic differentiation is induced by BMP9 (López-Coviella et al., 2000). However, there were no significant changes in BFCN differentiation in $\mathrm{Rla} \mathrm{KO}$ animals (data not shown). This likely reflects the presence of intact ALK1, the major type I receptor for BMP9 (Upton et al., 2009). Thus the hypophagia and weight loss in R1a KO mice does not involve disruption of cholinergic neurons. OLIG1 progenitors also generate cortical interneurons (Samanta et al., 2007; Mukhopadhyay et al., 2009). Although unlikely, changes in forebrain interneurons could contribute to the hypophagia observed in R1a KO mice.

BMP7 is required for specification of $\mathrm{NKX}_{2} .1^{+}$progenitorderived arcuate neurons (Ohyama et al., 2005). Consistent with reports that BMP7 acts on postmitotic cells that are ventralized by $\mathrm{SHH}$ to induce dopaminergic differentiation, we observed no changes in progenitor proliferation in $\mathrm{R} 1 \mathrm{a} \mathrm{KO}$ animals. Our observation of reduced ASCL1 and DLX2 expression in ARH suggests a role for BMPR1A signaling in neuronal differentiation. However, the reduced number of DLX2 ${ }^{+}$cells in embryos does not lead to reduced numbers of postnatal DLX2 ${ }^{+}$neurons. It is possible that reduced numbers of $\mathrm{DLX}_{2}{ }^{+}$neurons in $\mathrm{R} 1 \mathrm{a} \mathrm{KO}$ mice are still functionally sufficient after birth. Alternatively, different circuit properties resulting from DLX $2{ }^{+}$neuron reduction 
may elicit compensatory changes, including recruitment of other ARH neurons to become DLX2 ${ }^{+}$/GABAergic. This hypothesis is supported by our observation that DLX2 ${ }^{+}$neuron numbers increase at P14 and P21. However, it is unclear whether this increase is a result of hypophagia or contributes to the behavioral phenotype. GABAergic signaling has recently been shown to be critical for the orexigenic function of AgRP neurons(Wu et al., 2009; Vong et al., 2011), and the observed DLX2 expression increase correlates well with the need to increase GABAergic/orexigenic signaling as result of hypophagia.

Nevertheless, the profound reduction of $\mathrm{AgRP}^{+}$terminals in ARH target nuclei of R1a KO mice likely prevented the transduction of orexigenic signals. Our in vitro findings strongly suggest that this reduction is the result of defective neurite outgrowth of ARH neurons, as inhibition of BMP signaling by noggin or R1A deletion prevented leptin-induced neurite outgrowth of cultured ARH explants. It has been suggested that leptin preferentially activates pSTAT3 and increases the density of orexigenic AgRP ${ }^{+}$ fibers during postnatal development (Blackshaw et al., 2010; Bouret et al., 2012). These findings raise the possibility that reduced neurite outgrowth in ARH explants observed with BMP signaling inhibition might be specific to $\mathrm{AgRP}^{+}$neurons and contributes to hypophagia. However, postnatal ablation of AgRP neurons has been shown to not affect feeding behavior in the adult (Luquet et al., 2005), suggesting that compensatory mechanisms are likely in place to relay orexigenic signals originally mediated by the lost AgRP neurons. The Olig1 lineage also contributes to other hypothalamic nuclei including the ventral medial hypothalamus (VMH), which is known to participate in leptin-regulated feeding behavior(Dhillon et al., 2006; Bingham et al., 2008; Zhang et al., 2008). Our observation of leptininduced BMP signaling activation in the VMH suggests BMPR1A may also regulate the development of VMH-mediated circuits, which in turn contribute to hypophagia observed in R1a KO mice.

Increased SMAD1/5/8 phosphorylation in ventral hypothalamus 45 min after leptin injection suggests that BMPR activation rapidly responds to elevated leptin concentrations. The leptin receptor has been shown to physically interact with LRP1 (Liu et al., 2011), a low-density lipoprotein receptor-related protein that functions as a TGF- $\beta$ coreceptor in the vascular system (Boucher et al., 2007). However, direct interaction between leptin receptor and BMPR1A has not been reported. In the ARH, $\mathrm{AgRP}^{+}$neurons show a small but significant increase of pSMAD1/5/8 $3 \mathrm{~h}$ after leptin injection, following the increase of pSTAT3 observed at $45 \mathrm{~min}$ after leptin injection. Sequential activation of pSTAT3 and PSMAD has been reported during astrogliogenesis, during which leukemia inhibitory factor activated pSTAT3 promotes BMP2 expression that leads to commitment of neural stem cells to the astrocyte lineage (Fukuda et al., 2007). Further examination of pSTAT3 transcriptional targets in the ARH neurons would help address the possibility that pSTAT3 and PSMAD signaling are linked.

There are precedents for BMP promoting neurite outgrowth (Li et al., 1998; Zhang et al., 1998; Iwasaki et al., 1999). Developmentally, BMP7 regulates the guidance and extension of commissural axons in embryonic spinal cord (Butler and Dodd, 2003) Unlike our observation in the ARH, these effects of BMP7 are mediated by BMPR1B instead of BMPR1A (Yamauchi et al., 2008). Expression of BMP7 is present in the embryonic ventral hypothalamus, and is found postnatally in meningeal cells adjacent to the ARH during leptin-dependent neurite outgrowth (Söderström and Ebendal, 1999; Ohyama et al., 2008; Choe et al.,
2012). These findings suggest that BMP7 may act as the ligand for BMPR1A-expressing ARH neurons. Our study again highlighted the functional diversity of type 1 BMPR subtypes, which has been shown to perform distinct physiological roles in other systems (Sahni et al., 2010). BMPR II, through SMAD independent regulation of LIM kinase and Cofilin activation, has also been implicated in axon turning and extension (Wen et al., 2007; Phan et al., 2010). While it is currently unclear what downstream target of BMPR1A is responsible for the observed phenotype, our findings clearly demonstrate that BMPR1A signaling is essential for the perinatal development and establishment of ARH neuronal circuits.

\section{References}

Ahima RS, Prabakaran D, Flier JS (1998) Postnatal leptin surge and regulation of circadian rhythm of leptin by feeding. Implications for energy homeostasis and neuroendocrine function. J Clin Invest 101:1020-1027. CrossRef Medline

Anderson SA, Eisenstat DD, Shi L, Rubenstein JL (1997) Interneuron migration from basal forebrain to neocortex: dependence on Dlx genes. Science 278:474-476. CrossRef Medline

Anderson S, Mione M, Yun K, Rubenstein JL (1999) Differential origins of neocortical projection and local circuit neurons: role of Dlx genes in neocortical interneuronogenesis. Cereb Cortex 9:646-654. CrossRef Medline

Bates SH, Stearns WH, Dundon TA, Schubert M, Tso AW, Wang Y, Banks AS, Lavery HJ, Haq AK, Maratos-Flier E, Neel BG, Schwartz MW, Myers MG $\mathrm{Jr}$ (2003) STAT3 signalling is required for leptin regulation of energy balance but not reproduction. Nature 421:856-859. CrossRef Medline

Berglund EO, Murai KK, Fredette B, Sekerkov á G, Marturano B, Weber L, Mugnaini E, Ranscht B (1999) Ataxia and abnormal cerebellar microorganization in mice with ablated contactin gene expression. Neuron 24: 739-750. CrossRef Medline

Bingham NC, Anderson KK, Reuter AL, Stallings NR, Parker KL (2008) Selective loss of leptin receptors in the ventromedial hypothalamic nucleus results in increased adiposity and a metabolic syndrome. Endocrinology 149:2138-2148. CrossRef Medline

Blackshaw S, Scholpp S, Placzek M, Ingraham H, Simerly R, Shimogori T (2010) Molecular pathways controlling development of thalamus and hypothalamus: from neural specification to circuit formation. J Neurosci 30:14925-14930. CrossRef Medline

Bonaguidi MA, Peng CY, McGuire T, Falciglia G, Gobeske KT, Czeisler C, Kessler JA (2008) Noggin expands neural stem cells in the adult hippocampus. J Neurosci 28:9194-9204. CrossRef Medline

Boucher P, Li WP, Matz RL, Takayama Y, Auwerx J, Anderson RG, Herz J (2007) LRP1 functions as an atheroprotective integrator of TGFbeta and PDFG signals in the vascular wall: implications for Marfan syndrome. PLoS One 2:e448. CrossRef Medline

Bouret SG, Simerly RB (2007) Development of leptin-sensitive circuits. J Neuroendocrinol 19:575-582. CrossRef Medline

Bouret SG, Draper SJ, Simerly RB (2004) Trophic action of leptin on hypothalamic neurons that regulate feeding. Science 304:108-110. CrossRef Medline

Bouret SG, Bates SH, Chen S, Myers MG Jr, Simerly RB (2012) Distinct roles for specific leptin receptor signals in the development of hypothalamic feeding circuits. J Neurosci 32:1244-1252. CrossRef Medline

Butler SJ, Dodd J (2003) A role for BMP heterodimers in roof platemediated repulsion of commissural axons. Neuron 38:389-401. CrossRef Medline

Caqueret A, Yang C, Duplan S, Boucher F, Michaud JL (2005) Looking for trouble: a search for developmental defects of the hypothalamus. Horm Res 64:222-230. CrossRef Medline

Cheung CC, Clifton DK, Steiner RA (1997) Proopiomelanocortin neurons are direct targets for leptin in the hypothalamus. Endocrinology 138: 4489-4492. CrossRef Medline

Choe Y, Siegenthaler JA, Pleasure SJ (2012) A cascade of morphogenic signaling initiated by the meninges controls corpus callosum formation. Neuron 73:698-712. CrossRef Medline

Cone RD (2005) Anatomy and regulation of the central melanocortin system. Nat Neurosci 8:571-578. CrossRef Medline

Cowley MA, Smart JL, Rubinstein M, Cerdán MG, Diano S, Horvath TL, 
Cone RD, Low MJ (2001) Leptin activates anorexigenic POMC neurons through a neural network in the arcuate nucleus. Nature 411:480-484. CrossRef Medline

Daza RA, Englund C, Hevner RF (2007) Organotypic slice culture of embryonic brain tissue. CSH Protoc 2007:pdb prot4914. CrossRef Medline

Dhillon H, Zigman JM, Ye C, Lee CE, McGovern RA, Tang V, Kenny CD, Christiansen LM, White RD, Edelstein EA, Coppari R, Balthasar N, Cowley MA, Chua S Jr, Elmquist JK, Lowell BB (2006) Leptin directly activates $\mathrm{SF} 1$ neurons in the $\mathrm{VMH}$, and this action by leptin is required for normal body-weight homeostasis. Neuron 49:191-203. CrossRef Medline

Erickson JC, Hollopeter G, Palmiter RD (1996) Attenuation of the obesity syndrome of ob/ob mice by the loss of neuropeptide Y. Science 274:17041707. CrossRef Medline

Fetissov SO, Bergström U, Johansen JE, Hökfelt T, Schalling M, Ranscht B (2005) Alterations of arcuate nucleus neuropeptidergic development in contactin-deficient mice: comparison with anorexia and food-deprived mice. Eur J Neurosci 22:3217-3228. CrossRef Medline

Fetissov S, Meguid MM, Miyata G, Torelli GF, Shafiroff M (2000) VMN dopaminergic graft and feeding pattern in obese Zucker rats. Int J Obes Relat Metab Disord 24:376-381. CrossRef Medline

Fukuda S, Abematsu M, Mori H, Yanagisawa M, Kagawa T, Nakashima K, Yoshimura A, Taga T (2007) Potentiation of astrogliogenesis by STAT3mediated activation of bone morphogenetic protein-Smad signaling in neural stem cells. Mol Cell Biol 27:4931-4937. CrossRef Medline

Furusho M, Ono K, Takebayashi H, Masahira N, Kagawa T, Ikeda K, Ikenaka $\mathrm{K}$ (2006) Involvement of the Olig2 transcription factor in cholinergic neuron development of the basal forebrain. Dev Biol 293:348-357. CrossRef Medline

Gautron L, Elmquist JK (2011) Sixteen years and counting: an update on leptin in energy balance. J Clin Invest 121:2087-2093. CrossRef Medline

Gross RE, Mehler MF, Mabie PC, Zang Z, Santschi L, Kessler JA (1996) Bone morphogenetic proteins promote astroglial lineage commitment by mammalian subventricular zone progenitor cells. Neuron 17:595-606. CrossRef Medline

Gulacsi A, Lillien L (2003) Sonic hedgehog and bone morphogenetic protein regulate interneuron development from dorsal telencephalic progenitors in vitro. J Neurosci 23:9862-9872. Medline

Hnasko TS, Perez FA, Scouras AD, Stoll EA, Gale SD, Luquet S, Phillips PE, Kremer EJ, Palmiter RD (2006) Cre recombinase-mediated restoration of nigrostriatal dopamine in dopamine-deficient mice reverses hypophagia and bradykinesia. Proc Natl Acad Sci U S A 103:8858-8863. CrossRef Medline

Iwasaki S, Iguchi M, Watanabe K, Hoshino R, Tsujimoto M, Kohno M (1999) Specific activation of the p38 mitogen-activated protein kinase signaling pathway and induction of neurite outgrowth in PC12 cells by bone morphogenetic protein-2. J Biol Chem 274:26503-26510. CrossRef Medline

Johansen JE, Fetissov S, Fischer H, Arvidsson S, Hökfelt T, Schalling M (2003) Approaches to anorexia in rodents: focus on the anx/anx mouse. Eur J Pharmacol 480:171-176. CrossRef Medline

Kessaris N, Fogarty M, Iannarelli P, Grist M, Wegner M, Richardson WD (2006) Competing waves of oligodendrocytes in the forebrain and postnatal elimination of an embryonic lineage. Nat Neurosci 9:173-179. CrossRef Medline

Larder R, Clark DD, Miller NL, Mellon PL (2011) Hypothalamic dysregulation and infertility in mice lacking the homeodomain protein Six6. J Neurosci 31:426-438. CrossRef Medline

Letinic K, Zoncu R, Rakic P (2002) Origin of GABAergic neurons in the human neocortex. Nature 417:645-649. CrossRef Medline

Li W, Cogswell CA, LoTurco JJ (1998) Neuronal differentiation of precursors in the neocortical ventricular zone is triggered by BMP. J Neurosci 18:8853-8862. Medline

Liu Q, Zhang J, Zerbinatti C, Zhan Y, Kolber BJ, Herz J, Muglia LJ, Bu G (2011) Lipoprotein receptor LRP1 regulates leptin signaling and energy homeostasis in the adult central nervous system. PLoS Biol 9:e1000575. CrossRef Medline

Lo L, Sommer L, Anderson DJ (1997) MASH1 maintains competence for BMP2-induced neuronal differentiation in post-migratory neural crest cells. Curr Biol 7:440-450. CrossRef Medline

Lo L, Tiveron MC, Anderson DJ (1998) MASH1 activates expression of the paired homeodomain transcription factor Phox $2 \mathrm{a}$, and couples pan- neuronal and subtype-specific components of autonomic neuronal identity. Development 125:609-620. Medline

Long JE, Swan C, Liang WS, Cobos I, Potter GB, Rubenstein JL (2009) Dlx1\&2 and Mash1 transcription factors control striatal patterning and differentiation through parallel and overlapping pathways. J Comp Neurol 512:556-572. CrossRef Medline

López-Coviella I, Berse B, Krauss R, Thies RS, Blusztajn JK (2000) Induction and maintenance of the neuronal cholinergic phenotype in the central nervous system by BMP-9. Science 289:313-316. CrossRef Medline

Lu QR, Sun T, Zhu Z, Ma N, Garcia M, Stiles CD, Rowitch DH (2002) Common developmental requirement for Olig function indicates a motor neuron/oligodendrocyte connection. Cell 109:75-86. CrossRef Medline

Luquet S, Perez FA, Hnasko TS, Palmiter RD (2005) NPY/AgRP neurons are essential for feeding in adult mice but can be ablated in neonates. Science 310:683-685. CrossRef Medline

Maltais LJ, Lane PW, Beamer WG (1984) Anorexia, a recessive mutation causing starvation in preweanling mice. J Hered 75:468-472. Medline

McNay DE, Pelling M, Claxton S, Guillemot F, Ang SL (2006) Mash1 is required for generic and subtype differentiation of hypothalamic neuroendocrine cells. Mol Endocrinol 20:1623-1632. Medline

Mukhopadhyay A, McGuire T, Peng CY, Kessler JA (2009) Differential effects of BMP signaling on parvalbumin and somatostatin interneuron differentiation. Development 136:2633-2642. CrossRef Medline

Niswender KD, Morton GJ, Stearns WH, Rhodes CJ, Myers MG Jr, Schwartz MW (2001) Intracellular signalling. Key enzyme in leptin-induced anorexia. Nature 413:794-795. CrossRef Medline

Ohyama K, Ellis P, Kimura S, Placzek M (2005) Directed differentiation of neural cells to hypothalamic dopaminergic neurons. Development 132: 5185-5197. CrossRef Medline

Ohyama K, Das R, Placzek M (2008) Temporal progression of hypothalamic patterning by a dual action of BMP. Development 135:3325-3331. CrossRef Medline

Phan KD, Hazen VM, Frendo M, Jia Z, Butler SJ (2010) The bone morphogenetic protein roof plate chemorepellent regulates the rate of commissural axonal growth. J Neurosci 30:15430-15440. CrossRef Medline

Robert JJ, Orosco M, Rouch C, Cohen Y, Jacquot C (1990) Opposite dopaminergic activity in lateral and median hypothalamic nuclei in relation to the feeding effect of D-Ser2-Leu-Enk-Thr6 (DSLET). Brain Res 510:7-11. CrossRef Medline

Sahni V, Mukhopadhyay A, Tysseling V, Hebert A, Birch D, Mcguire TL, Stupp SI, Kessler JA (2010) BMPR1a and BMPR1b signaling exert opposing effects on gliosis after spinal cord injury. J Neurosci 30:1839-1855. CrossRef Medline

Samanta J, Burke GM, McGuire T, Pisarek AJ, Mukhopadhyay A, Mishina Y, Kessler JA (2007) BMPR1a signaling determines numbers of oligodendrocytes and calbindin-expressing interneurons in the cortex. J Neurosci 27:7397-7407. CrossRef Medline

Shi Y, Massagu é J (2003) Mechanisms of TGF-beta signaling from cell membrane to the nucleus. Cell 113:685-700. CrossRef Medline

Shimogori T, Lee DA, Miranda-Angulo A, Yang Y, Wang H, Jiang L, Yoshida AC, Kataoka A, Mashiko H, Avetisyan M, Qi L, Qian J, Blackshaw S (2010) A genomic atlas of mouse hypothalamic development. Nat Neurosci 13:767-775. CrossRef Medline

Shou J, Rim PC, Calof AL (1999) BMPs inhibit neurogenesis by a mechanism involving degradation of a transcription factor. Nat Neurosci 2:339345. CrossRef Medline

Söderström S, Ebendal T (1999) Localized expression of BMP and GDF mRNA in the rodent brain. J Neurosci Res 56:482-492. CrossRef Medline

Stephens TW, Basinski M, Bristow PK, Bue-Valleskey JM, Burgett SG, Craft L, Hale J, Hoffmann J, Hsiung HM, Kriauciunas A (1995) The role of neuropeptide $\mathrm{Y}$ in the antiobesity action of the obese gene product. Nature 377:530-532. CrossRef Medline

Stühmer T, Anderson SA, Ekker M, Rubenstein JL (2002) Ectopic expression of the Dlx genes induces glutamic acid decarboxylase and Dlx expression. Development 129:245-252. Medline

Szczypka MS, Rainey MA, Palmiter RD (2000) Dopamine is required for hyperphagia in Lep(ob/ob) mice. Nat Genet 25:102-104. CrossRef Medline

Szczypka MS, Kwok K, Brot MD, Marck BT, Matsumoto AM, Donahue BA, Palmiter RD (2001) Dopamine production in the caudate putamen restores feeding in dopamine-deficient mice. Neuron 30:819-828. CrossRef Medline 
Takebayashi H, Yoshida S, Sugimori M, Kosako H, Kominami R, Nakafuku M, Nabeshima Y (2000) Dynamic expression of basic helix-loop-helix Olig family members: implication of Olig2 in neuron and oligodendrocyte differentiation and identification of a new member, Olig3. Mech Dev 99:143-148. CrossRef Medline

Tartaglia LA, Dembski M, Weng X, Deng N, Culpepper J, Devos R, Richards GJ, Campfield LA, Clark FT, Deeds J, Muir C, Sanker S, Moriarty A, Moore KJ, Smutko JS, Mays GG, Wool EA, Monroe CA, Tepper RI (1995) Identification and expression cloning of a leptin receptor, OB-R. Cell 83:1263-1271. CrossRef Medline

Thornton JE, Cheung CC, Clifton DK, Steiner RA (1997) Regulation of hypothalamic proopiomelanocortin mRNA by leptin in ob/ob mice. Endocrinology 138:5063-5066. CrossRef Medline

Upton PD, Davies RJ, Trembath RC, Morrell NW (2009) Bone morphogenetic protein (BMP) and activin type II receptors balance BMP9 signals mediated by activin receptor-like kinase- 1 in human pulmonary artery endothelial cells. J Biol Chem 284:15794-15804. CrossRef Medline

Vaisse C, Halaas JL, Horvath CM, Darnell JE Jr, Stoffel M, Friedman JM (1996) Leptin activation of Stat3 in the hypothalamus of wild-type and $\mathrm{ob} / \mathrm{ob}$ mice but not db/db mice. Nat Genet 14:95-97. CrossRef Medline

Vong L, Ye C, Yang Z, Choi B, Chua S Jr, Lowell BB (2011) Leptin action on GABAergic neurons prevents obesity and reduces inhibitory tone to POMC neurons. Neuron 71:142-154. CrossRef Medline

Wen Z, Han L, Bamburg JR, Shim S, Ming GL, Zheng JQ (2007) BMP gradients steer nerve growth cones by a balancing act of LIM kinase and Slingshot phosphatase on ADF/cofilin. J Cell Biol 178:107-119. CrossRef Medline

Wu Q, Boyle MP, Palmiter RD (2009) Loss of GABAergic signaling by AgRP neurons to the parabrachial nucleus leads to starvation. Cell 137:12251234. CrossRef Medline

Xu AW, Ste-Marie L, Kaelin CB, Barsh GS (2007) Inactivation of signal transducer and activator of transcription 3 in proopiomelanocortin (Pomc) neurons causes decreased pomc expression, mild obesity, and defects in compensatory refeeding. Endocrinology 148:72-80. Medline
Yamauchi K, Phan KD, Butler SJ (2008) BMP type I receptor complexes have distinct activities mediating cell fate and axon guidance decisions. Development 135:1119-1128. CrossRef Medline

Yee CL, Wang Y, Anderson S, Ekker M, Rubenstein JL (2009) Arcuate nucleus expression of NKX2.1 and DLX and lineages expressing these transcription factors in neuropeptide $\mathrm{Y}(+)$, proopiomelanocortin $(+)$, and tyrosine hydroxylase $(+)$ neurons in neonatal and adult mice. J Comp Neurol 517:37-50. CrossRef Medline

Yuhki M, Yamada M, Kawano M, Iwasato T, Itohara S, Yoshida H, Ogawa M, Mishina Y (2004) BMPR1A signaling is necessary for hair follicle cycling and hair shaft differentiation in mice. Development 131:18251833. CrossRef Medline

Yung SY, Gokhan S, Jurcsak J, Molero AE, Abrajano JJ, Mehler MF (2002) Differential modulation of BMP signaling promotes the elaboration of cerebral cortical GABAergic neurons or oligodendrocytes from a common sonic hedgehog-responsive ventral forebrain progenitor species. Proc Natl Acad Sci U S A 99:16273-16278. CrossRef Medline

Zhang D, Mehler MF, Song Q, Kessler JA (1998) Development of bone morphogenetic protein receptors in the nervous system and possible roles in regulating trkC expression. J Neurosci 18:3314-3326. Medline

Zhang R, Dhillon H, Yin H, Yoshimura A, Lowell BB, Maratos-Flier E, Flier JS (2008) Selective inactivation of Socs3 in SF1 neurons improves glucose homeostasis without affecting body weight. Endocrinology 149: 5654-5661. CrossRef Medline

Zhang Y, Proenca R, Maffei M, Barone M, Leopold L, Friedman JM (1994) Positional cloning of the mouse obese gene and its human homologue. Nature 372:425-432. CrossRef Medline

Zhou QY, Palmiter RD (1995) Dopamine-deficient mice are severely hypoactive, adipsic, and aphagic. Cell 83:1197-1209. CrossRef Medline

Zhou Q, Wang S, Anderson DJ (2000) Identification of a novel family of oligodendrocyte lineage-specific basic helix-loop-helix transcription factors. Neuron 25:331-343. CrossRef Medline 